\title{
New information on the feeding habits of the percomorph Rhenanoperca minuta, together with a short look at other fish species from the Eocene Messel Formation of Germany
}

\author{
Norbert Micklich, Viktor Baranov \& Torsten Wappler
}

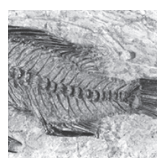

\begin{abstract}
Forage remains were studied in the digestive tracts of four Messel fish species (Rhenanoperca minuta, Thaumaturus intermedius, Cyclurus kehreri, Atractosteus messelensis). They were found in only 4\% of all samples. Particular attention was paid to $R$. minuta. Herein, depending on the investigation method, between $0.7 \%$ and $13 \%$ of the samples contained conspecific prey fish and/or prey fish remains. In total $1.6 \%$ contained remains of amphipod shrimps. Concerning T. intermedius, prey (arthropod) remains could be found only in one sample (3.4\%). Similarly, only one $(6.6 \%)$ of the bowfins (C. kehreri) and none of the gars (A. messelensis) contained such remains. The pharyngeal jaws of $R$. minuta exhibit two basic types of dentition. One is characterized by strong, flattened ("molariform") pharyngeal teeth, and the other by more delicate and slender ("papilliform") ones. This polymorphism may be indicative of a beginning or advancing speciation. The different morphotypes probably originated in adjacent water bodies (allopatric) rather than in Lake Messel itself (sympatric). The results were discussed with particular attention to extant comparable species. The high rate of evacuated digestive tracts in $R$. minuta very probably results from a shortage of suitable prey, and possibly also from environmental restrictions. For the other species, different factors, like diurnal or seasonal fluctuations may have played a more important role. For $R$. minuta, a diet switch from predominantly arthropods to fish, especially a switch to T. intermedius as a main prey, can be discarded. Rather there appears to have been a gradual transition from soft-bodied arthropods to gastropods, as known from comparable recent species, even actual though direct evidence (gastric or intestinal contents, or even co-occurrence with abundant gastropods) could not observed among the investigated fossils. - Key words: Messel Pit, actinopterygian fishes, nutrition, pharyngeal dentition, cannibalism, speciation.
\end{abstract}

Micklich, N., Baranov, V. \& Wappler, T. 2019. New information on the feeding habits of the percomorph Rhenanoperca minuta, together with a short look at other fish species from the Eocene Messel Formation of Germany. Bulletin of Geosciences 94(3), 315-336 (15 figures, 1 table). Czech Geological Survey, Prague. ISSN 1214-1119. Manuscript received August 21, 2018; accepted in revised from May 7, 2019; published online July 1, 2019; issued November 30, 2019.

Norbert Micklich, clo Natural History Department, Hessisches Landesmuseum Darmstadt, Friedensplatz 1, D.64283, Darmstadt, Germany; micklichnorbert@gmail.com • Viktor Baranov, Department of Biology II, LMU Munich, Großhaderner Str. 2, 82152, Planegg-Martinsried, Germany - Torsten Wappler, Natural History Department, Hessisches Landesmuseum Darmstadt, Friedensplatz 1, D.64283, Darmstadt, Germany

Reconstructions of fossil food webs typically are based on the assumption that the investigated fossils will have fed and behaved like their presumed closest extant relatives. Such studies suffer from a lack of direct evidence, such as forage remains preserved between the jaws, in the oral cavity, or within the digestive tract, which can be assigned to a certain producer (Boy 2003), although some direct coprolite evidence of food webs has been reported (e.g., Richter \& Baszio 2001a, Richter \& Wedmann 2005, O’Goghain et al. 2016).

The World Heritage Site of Grube Messel near Darmstadt (Hesse, Germany) is located about $9 \mathrm{~km}$ northeast of Darmstadt (Hessen State, S Germany). It is an ancient open-cast mining, in which oil-shales were quarried until 1971. These belong to the so-called Messel-Formation and are Middle Eocene in age (47 Ma, Mammal Stratigraphy Level MP 11). The fossil site is particularly famous for the preservation of soft tissue, especially in fossil mammals, which provides opportunities for investigating food remains in situ (Richter 1992, Storch 2001). As the sediments originated in an ancient lake, aquatic organisms, such as fish, can provide us with valuable information for the reconstruction of the paleoecological relationships. 
Based on macroscopic studies, Messel fish rarely contain forage remains in their mouths or inside their digestive tracts. This is in contrast to those from other contemporary fossil sites, that often are preserved with respective prey items in situ (e.g., Grande 2013), and may be indicative of different environmental conditions. Only a few examples of direct macroscopic evidence of predator-prey relationships in Messel fishes are known to date. Cannibalism has been reported in bowfins (Cyclurus kehreri Andreae, 1893) and in the small "shell-cracker" perch Rhenanoperca minuta Gaudant \& Micklich, 1990 (Eikamp 1982; Micklich 1985, 2007). Palaeoperca proxima Micklich, 1978 has been documented as the prey of Atractosteus messelensis Grande, 2010 (Micklich 1985, 2012a). Thaumaturus intermedius Weitzel, 1933 and $R$. minuta are known as the prey of Amphiperca multiformis Weitzel, 1933 (Micklich 1985). Furthermore, a dense cluster of pharyngeal teeth of $R$. minuta has been noticed in a bowfin specimen that was found by a team of the Hessisches Landesmuseum Darmstadt in winter of 2013/14 (M. Drobek, N. Micklich, personal observation). Finally, a fish tail, probably of $T$. intermedius, projects from the mouth of a larger bowfin (HLMD-Me 14954; $524 \mathrm{~mm}$ total length, $450 \mathrm{~mm}$ standard length, respectively) that is on display in the permanent Messel exhibition at the Hessisches Landesmuseum Darmstadt, Germany. Analysis of food remains in the digestive tract of the primitive teleostean fish $T$. intermedius suggests that it was strictly planktivorous/insectivorous, at least during the first year of its life (Richter \& Baszio 2001b). Insectivory in $T$. intermedius was further proven by the analysis of prey remains in another specimen by Micklich (2012b). In addition, Richter \& Baszio (2006) demonstrated that the digestive tract of the small "shellcracker" perch $R$. minuta contained remains of arthropod larvae and also of fish, presumably of $T$. intermedius.

Microscopic analyses of small-sized coprolites that were considered to have been produced by fish (e.g., Richter \& Baszio 2001a) are another source of food web data at the Messel site (Richter \& Wedmann 2005, Wedmann \& Richter 2007, Richter et al. 2017). Unfortunately, assigning coprolites to a particular fish species is difficult. According to the literature (e.g., Carlander 1977, 1997), the juveniles of closely related extant forms, or of those that can be considered as the ecological equivalents of the Messel fish species, consume arthropods before they switch to other food resources later on. This can, therefore, also be assumed for the latter.

The general scarcity of direct evidence of prey remains in Messsel fishes, together in combination with some discrepancies between the results of the former investigations and morphological characteristics of certain species, was the reason for starting the present re-investigation.
Anatomical and institutional abbreviations. - GVI gastric vacuity index (number of empty stomaches found $\times 100$ divided through the number of stomaches analysed); HLMD - Hessisches Landesmuseum Darmstadt, Germany; HLMD-Me - Messel collections of the HLMD; HLMD-SMFR - extant fish comparative collection of the first author at HLMD; "HLMD" plus year and number - refers to the respective excavation areas; $\mathrm{Nl}$ neurocranial length (tip of the vomer to the posterior margin of supraoccipital); $\mathrm{Sl}$ - standard length (tip of the snout to the end of vertebral column); SMF - Senckenberg Research Institute, Frankfurt am Main, Germany SMF-ME - Messel collection of the SMF; "specimen" plus year and number - refers to the respective field book entry; $\mathrm{Tl}$ - total length (tip of the snout to the posterior margin of the caudal fin).

\section{Materials and methods}

\section{Fossils}

A total of 832 samples from the abdominal cavities of 711 Messel fish specimens were investigated with particular regard to preserved food remains. The majority of the specimens were prepared according to the standard method for all Messel fossils, during which the original fossil substance is transferred in the laboratory onto an artificial matrix, that consists of epoxy or polyester resin (for details, see Micklich \& Drobek 2007). Those that were mounted on micro-glass slides were prepared according to the method described by Roth \& Micklich (2006), and those that were directly prepared during field work were either transferred on an pre-formatted Eternit plate or a synthetic resin filler, according to the method described by Kaiser \& Micklich (1995). In addition, samples from fresh, unprepared specimens were directly taken during fieldwork. The radiographs were provided to us by different persons (see acknowledgements) and were prepared with different techniques and machines depending on the available laboratory equipment. For topographical and stratigraphical provenance of the investigated materials see Figs 1, 2, for general composition and size of the specimens and samples see Fig. 3 and Tab. 1. General information concerning the geological and palaeontological framework as well as further particulars concerning the Messel Pit is (i.a.) provided by Schaal \& Ziegler (1992).

All transfer-prepared specimens of $R$. minuta were also investigated in terms of their type of pharyngeal dentition, either by direct observations or in the radiographs. In addition, 67 specimens that were directly prepared during fieldwork were also examined in this manner. 


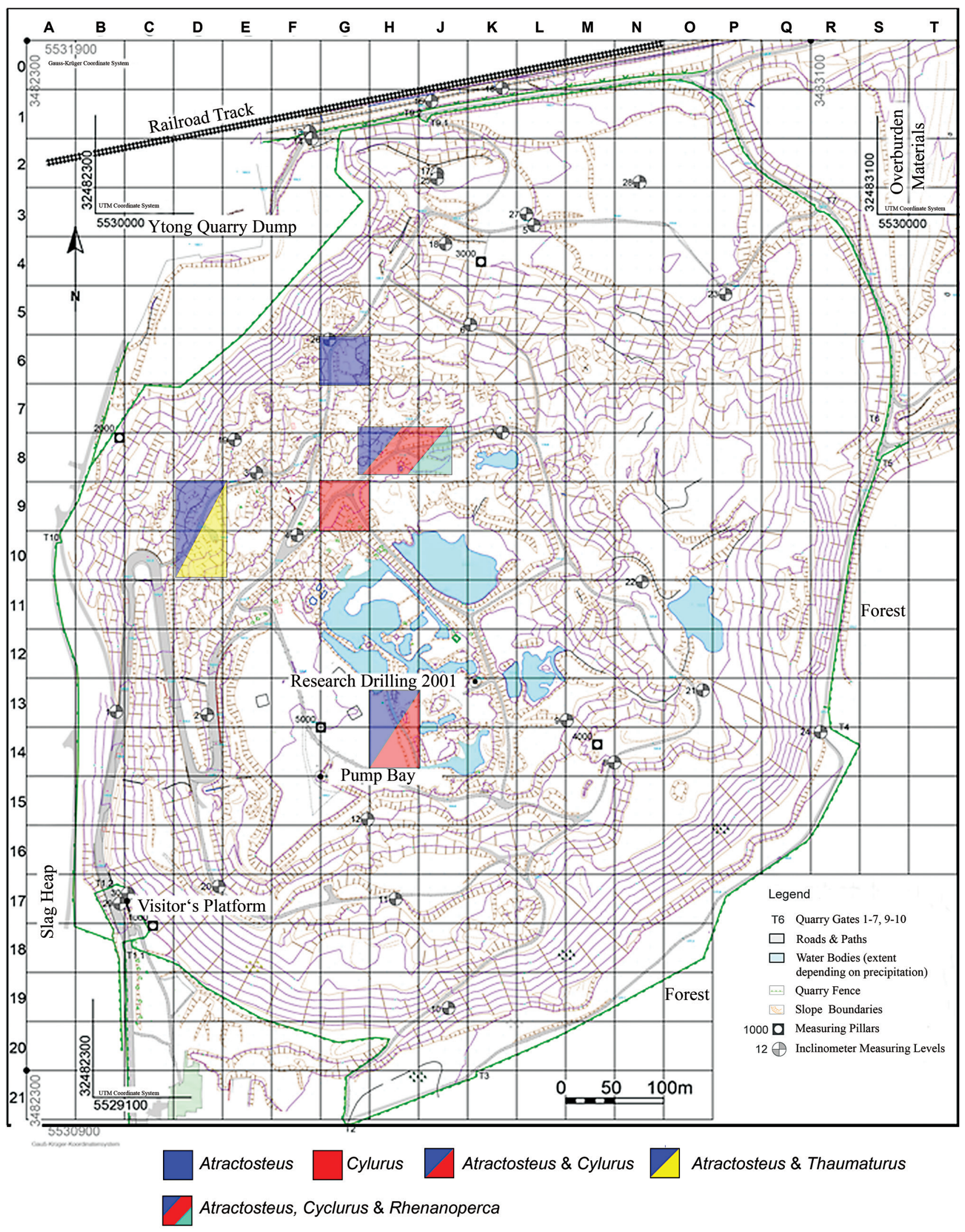

Figure 1. Topographic map of the Messel Pit, showing the grid squares from which the majority of the investigated materials is derived (modified from Schaal \& Rabenstein 2012). 
Table 1. Synopsis of materials: Type and size of investigated specimens/samples. Abbreviations: Tl, S1 - total and standard lengths (the values are rounded up, respectively down, to whole numbers); ${ }^{1}$ numbers in brackets - indicate how many of these specimens consisted of single plates, part and counterpart, respectively; ${ }^{2}$ numbers in brackets - indicate from how many specimens these sample were extracted from (some are sampled more than once). "Old collection" refers to materials that were found and prepared before the consistent application of the transfer method. These either are paraffin preparations or they are preserved in the dried and hardened original oil shale. For explanations of the different preparation and sampling methods also see the section "Fossils".

\begin{tabular}{|c|c|c|c|c|c|c|c|}
\hline Species, Type of Preparation & $\begin{array}{c}\text { No. of Specimens/ } \\
\text { Samples }\end{array}$ & $\begin{array}{l}\text { Tl min. } \\
{[\mathrm{mm}]}\end{array}$ & $\begin{array}{l}\mathrm{Tl} \max . \\
{[\mathrm{mm}]}\end{array}$ & $\begin{array}{c}\text { Tl mean } \\
{[\mathrm{mm}]}\end{array}$ & $\begin{array}{l}\text { S1 min. } \\
{[\mathrm{mm}]}\end{array}$ & $\begin{array}{l}\text { Sl max. } \\
{[\mathrm{mm}]}\end{array}$ & $\begin{array}{c}\text { S1 mean } \\
{[\mathrm{mm}]}\end{array}$ \\
\hline \multicolumn{8}{|l|}{ Rhenanoperca minuta } \\
\hline Standard transfer & 367 & 5 & 89 & 48 & 4 & 72 & 39 \\
\hline Old collection & 62 & - & - & - & - & - & - \\
\hline Transfer on micro glass slides & $139(93+46)^{1}$ & 10 & 50 & 31 & 8 & 40 & 26 \\
\hline Rapid transfer during field work & 67 & - & - & - & - & - & - \\
\hline Samples from unprepared specimens & $123(86)^{2}$ & 12 & 62 & 28 & 10 & 50 & 22 \\
\hline Radiographs & 54 & 18 & 96 & 40 & 16 & 77 & 33 \\
\hline \multicolumn{8}{|l|}{ Thaumaturus intermedius } \\
\hline Micro glass slides & $29(13+16)^{1}$ & 36 & 103 & 52 & 30 & 85 & 43 \\
\hline Unprepared & 9 & 43 & 54 & 49 & 36 & 45 & 40 \\
\hline \multicolumn{8}{|l|}{ Cyclurus kehreri } \\
\hline Standard transfer & $15(37)^{2}$ & 213 & 319 & 255 & 183 & 275 & 219 \\
\hline \multicolumn{8}{|l|}{ Atractosteus strausi } \\
\hline Standard transfer & $12(9)^{2}$ & 213 & 320 & 290 & 185 & 285 & 232 \\
\hline
\end{tabular}

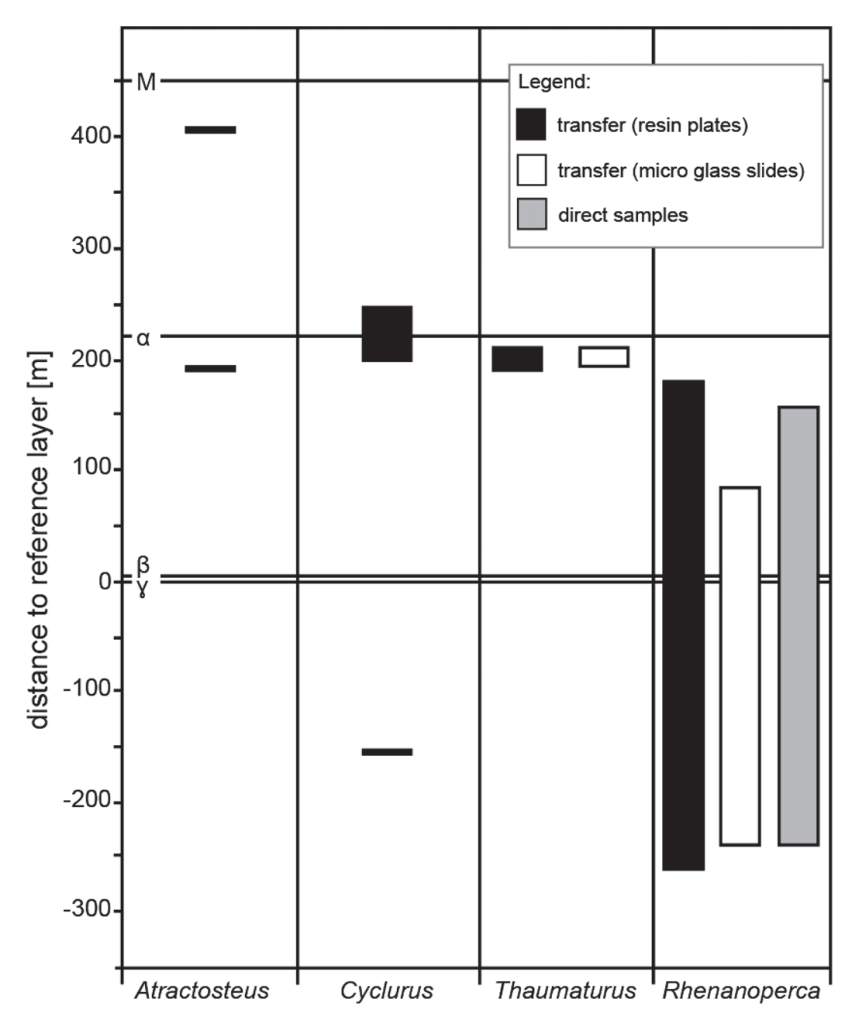

Figure 2. Stratigraphic provenance of the investigated materials, as far as reconstructable. Abbreviations: $\alpha, \beta, \gamma, \mathrm{M}$ - main reference layers within the oil shale.

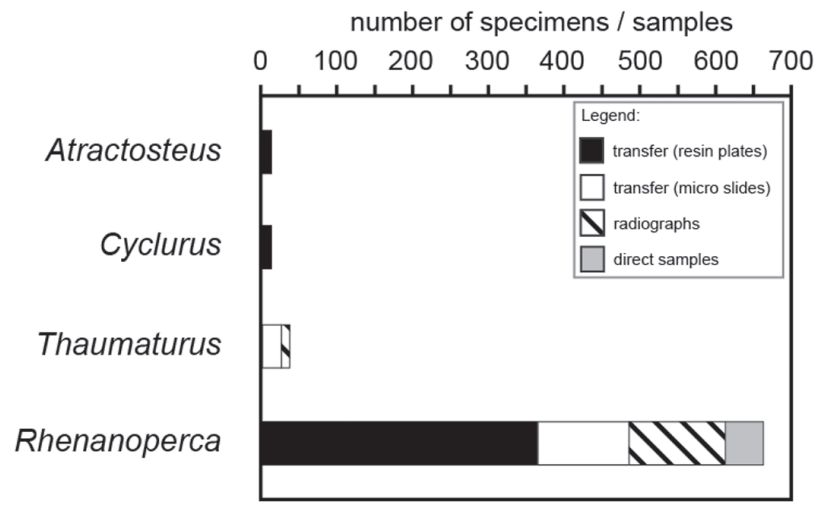

Figure 3. Synopsis of materials: general composition of investigated specimens and samples. For explanation of the different preparation and sampling methods see the section "Fossils".

\section{Extant comparative materials}

All specimens referred to herein belonged to five different species and consisted of the following specimens: Lepomis gibbosus (Linnaeus, 1758), Pumpkinseed: 3 cleared and alizarin-stained specimens (HLMD-SMFR 03, 115, 311), 80 to $126 \mathrm{~mm} \mathrm{Tl} \mathrm{(65} \mathrm{to} 102 \mathrm{~mm} \mathrm{Sl}$ ). Lepomis macrochirus Rafinesque, 1819, Bluegill: 1 cleared and stained specimen (HLMD-SMFR 241), $48 \mathrm{~mm}$ Tl (39 mm Sl). Lepomis microlophus (Günther, 1859), Redear sunfish: 


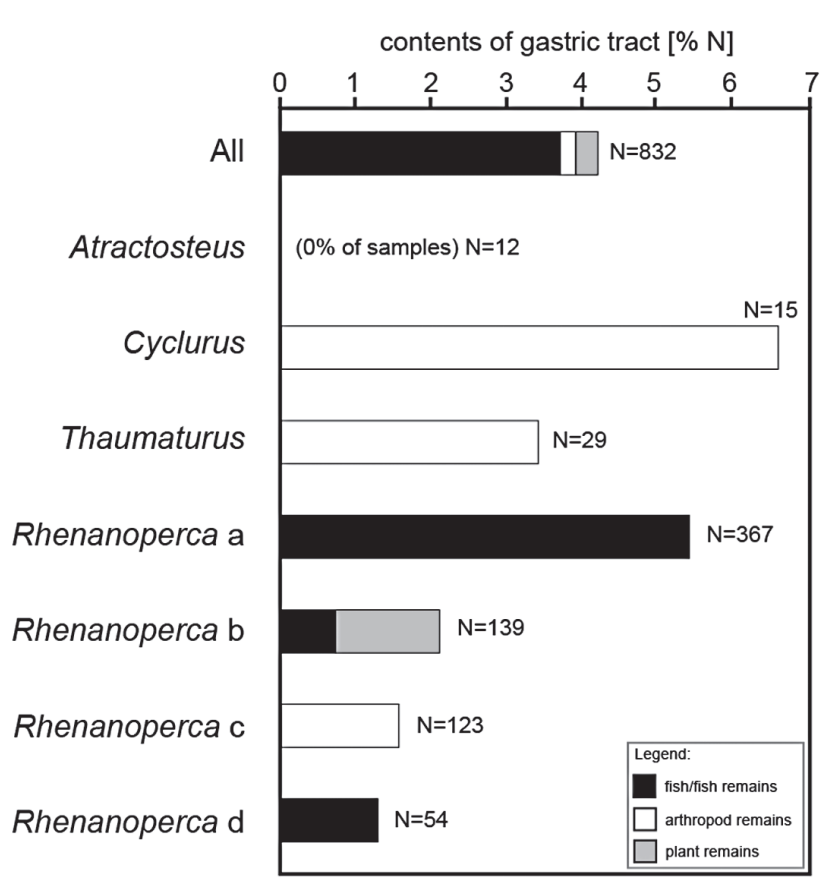

Figure 4. Synopsis of the contents of the digestive tract in Messel fishes. Abbreviation: $\mathrm{N}$ - total number of examined samples, specimens respectively. Arthropod and plant remains probably are over-represented because of the low N-values in the majority of the samples. Atractosteus, Cyclurus - data from samples from the abdominal cavity of unprepared and transfer-prepared specimens; Thaumaturus - combined data from specimens mounted on micro-glass slides and direct samples; Rhenanoperca a - data from transfer-prepared specimens; Rhenanoperca $\mathrm{b}$ - data from specimens mounted on micro-glass slides; Rhenanoperca $\mathrm{c}$ - data from direct samples; Rhenanoperca $\mathrm{d}$ - data from radiographs.

1 cleared and stained specimen (HLMD-SMFR 239), $51 \mathrm{~mm} \mathrm{Tl}(46 \mathrm{~mm} \mathrm{Sl})$. Micropogonias undulatus (Linnaeus, 1766), Atlantic croaker: 3 cleared and stained specimens (HLMD-SMFR 115, 311, 313), 129 to $140 \mathrm{~mm}$ $\mathrm{Tl}$ (100 to $110 \mathrm{~mm} \mathrm{Sl}$ ). Morone chrysops (Rafinesque, 1820), White bass: 1 cleared and stained specimen (HLMD-SMFR 31), $139 \mathrm{~mm}$ Tl (120 mm Sl).

\section{Investigation and documentation}

All fossil samples, including those from the unprepared specimens, were extracted with a preparation needle from the region of the abdominal cavity. They were rinsed in clean water and then bleached in a weak solution of hydrogen peroxide $\left(\mathrm{H}_{2} \mathrm{O}_{2}\right)$ in order to lighten the dark background sediment as well as remaining remnants of the body substance. They were then slowly air-dried, mounted on micro-glass slides, and protected by a standard cover slip. The samples from the digestive tracts of the extant comparative species were extracted with fine tweezers and/or a scalpel, and then rinsed, bleached and mounted in the same manner as those of the fossils.
All types of samples, as well as the radiographs, were examined with an Olympus BH 2 polarizing microscope with an $\mathrm{XY}$ stage. Presumed prey item remains were photographed with a Canon EOS 400D photographic attachment. The pictures were stored together with their respective $\mathrm{XY}$ coordinates to facilitate their retrieval later on.

\section{Analysis of the pharyngeal dentition}

The samples of the pharyngeal dentition from the nonprepared specimens were taken and examined in a similar manner; however, they were mounted on the micro-glass slides without prior bleaching.

In those specimens that were directly prepared during fieldwork, the resin does not penetrate and fix the fossil as completely as in the classic transfer method. As a result, superficial elements, like the opercles, either come off by themselves or can be removed more easily, so that the underlying pharyngeal region is exposed for study.

The samples from the transfer-prepared bowfins and gars were extracted, treated, analysed and documented the same way as those of the non-prepared specimens.

\section{Results}

\section{Contents of the digestive tract}

Of the total 832 samples that were analysed in the 711 specimens (some have been sampled multiple times), only $33(4 \%)$ contained remains of forage items at all: Of these, $31(3.8 \%)$ consisted of fish and two $(0.2 \%)$ of plant matter and crustacean remains, respectively.

Rhenanoperca minuta Gaudant \& Micklich, 1990. Looking at the details, of the 367 transfer prepared specimens of this species, 20 (5.4\%) were preserved with fish, respectively fish remains, either in their mouth and/or oral cavity or as contents of their digestive tract (Fig. 5A). The latter all consisted of smaller specimens of the same species. Such cannibalism occurred both in rather small specimens (e.g., HLMD-Me 11664; $25.42 \mathrm{~mm}$ Tl, $20.5 \mathrm{~mm}$ $\mathrm{Sl})$ as well as in larger ones (e.g., HLMD-Me 10352; $65 \mathrm{~mm} \mathrm{Tl}, 52 \mathrm{~mm} \mathrm{Sl}$ ). Where measurable, the lengths of the prey specimens ranged between 28.3 (HLMD-Me 15837 ) and $69.6 \%$ (HLMD-Me 11664) of the length of the respective predator. No prey fish remains were found in the 62 specimens from the old collection, which probably was due to imperfect preparation. Of the 139 specimens that were completely mounted on micro-glass slides, only one $(0.7 \%)$ contained remains of a prey fish that, once again, consisted of a smaller conspecific individual (HLMD-Me 
13448, Fig. 5B). Two specimens (1.4\%: HLMD-Me 13087 , HLMD-Me 2003-3 Ex. 23) contained plant remains, possibly a trichome of a leaf of Quercus sp., similar to those that often were found in Baltic amber (Wichard et al. 2009). A bunch of other specimens contained isolated teeth of various shape (Fig. 5C-E). These either were pharyngeal teeth from the same individual that were randomly also taken during the sampling process or those that were "naturally" displaced posteriorly during fossilisation. They
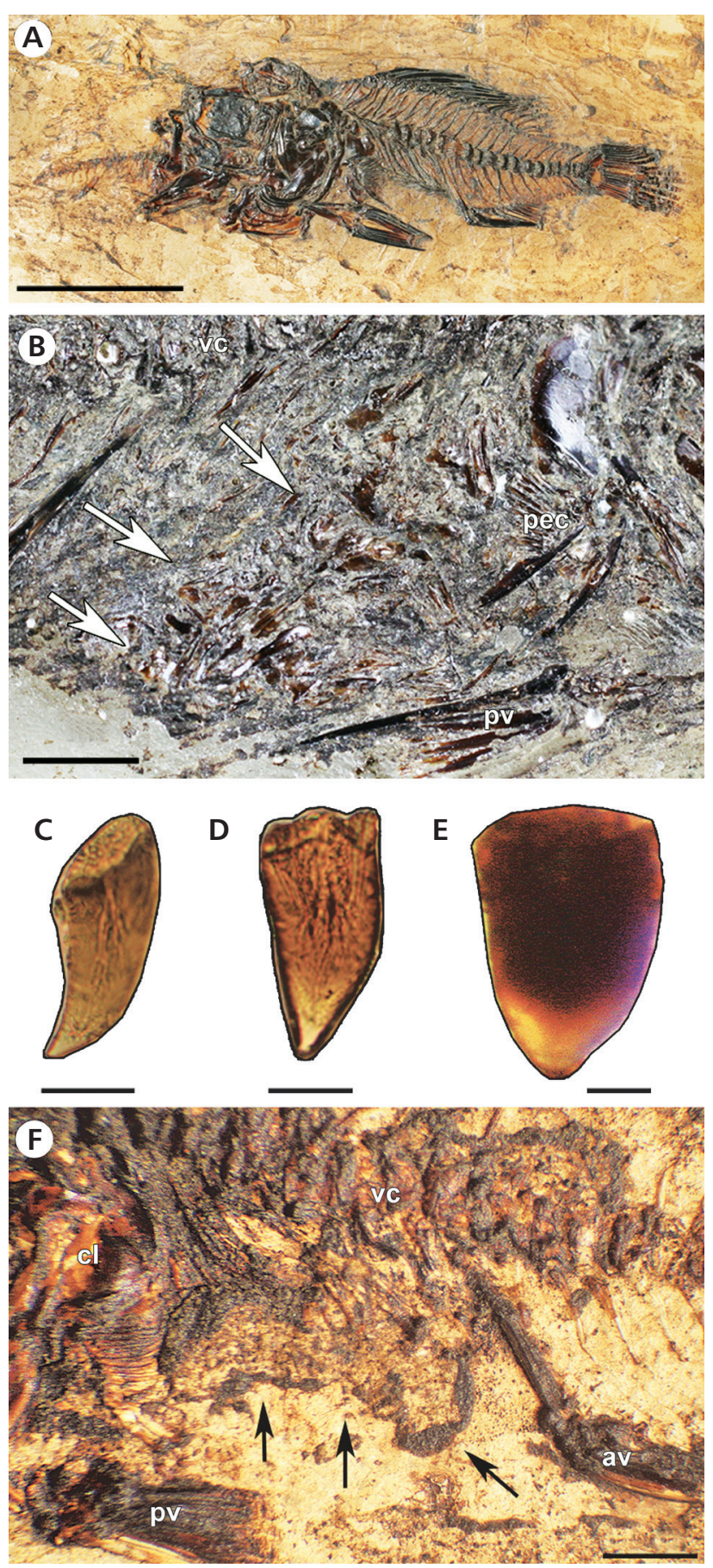

also may represent undigested remains of ingested smaller conspecific individuals. In any case, they all belong to $R$. minuta and not to any other Messel fish species. Others contained small masses of unidentifiable particles that also may have formed part of the contents of their digestive tracts (Fig. 5F). Last but not least, according to the 123 samples from the 86 non-prepared specimens, and aside from several instances in which isolated pharyngeal teeth also were preserved, only two $(1.6 \%)$ contained arthropod remains (i.e., HLMD-Me 2003-3 Ex 41a, b; HLMD-Me 2005-3 Ex. 171a, b; Fig. 6A, B). Interestingly, both probably are from amphipod shrimps and, therefore, clearly differ from the "stomach" contents in previous investigations (Richter \& Baszio 2001a, 2006) that mainly consisted of larval and pupal remains of phantom midges (Chaoboridae) and mosquitoes (Culicidae). One consists of leg or uropod fragments without further identification, the other may be from the inner part or endopodite of the left maxilla one of a crustacean (Fig. 6C). Interestingly, this second one almost exactly matches remains that were found within the digestive tract samples of the extant White bass, Morone chrysops (Fig. 6D). Both probably belong to a gammarid shrimp (Fig. 6E, F). As far as the radiographs are concerned, all were taken from $R$. minuta. Seven $(12.9 \%)$ from a total of 54 examined specimens contained prey fish and/or prey fish remains either in their mouths or in their digestive tracts (Fig. 7A, B). Once again, and as far as these could be identified, they consisted of smaller conspecific individuals.

Thaumaturus intermedius Weitzel, 1933. - In this species, and in contrast to the results obtained by Richter \& Baszio (2001b), aside from scale remains that very probably originated from the investigated specimen itself, identifiable arthropod remains only could be found in one of the 29 specimens that were transferred and completely

Figure 5. Prey items and contents of the digestive tract in Rhenanoperca minuta; A - HLMD-Me 12505, $33.1 \mathrm{~mm} \mathrm{Tl} \mathrm{(26.7} \mathrm{cm} \mathrm{S1),}$ transfer-prepared individual with a smaller conspecific prey specimen projecting from the mouth; B - HLMD-Me 13448, $42.53 \mathrm{~mm} \mathrm{T1}$ (34.3 $\mathrm{mm} \mathrm{S1),} \mathrm{transfer-prepared} \mathrm{specimen} \mathrm{mounted} \mathrm{on} \mathrm{a} \mathrm{micro-glass}$ slide, with a conspecific prey specimen in its digestive tract (marked by arrows), transmitted light; C - HLMD 2003-3, specimen 78a-124-13.5 (former 2003-3-179 78a, b), $15.5 \mathrm{~mm} \mathrm{Tl}$ (16.5 mm S1), a single curved, slender and pointed pharyngeal tooth (the photo is flipped horizontally to obtain a uniform orientation of all teeth) that was found in samples taken directly from the abdominal cavity of non-prepared fresh materials during field work, transmitted light; D - same, robust and straight conical tooth; E - HLMD 2003-3, specimen 58a, b, $36.33 \mathrm{~mm}$ Tl (29.3 mm Sl), massive and weakly pointed crushing tooth that does not show any traces of weared margins, transmitted light; F - HLMD-Me 13100a, 30.50 mm T1 $(24.6 \mathrm{~cm} \mathrm{S1})$, transfer-prepared specimen, mounted on a micro-glass slide, with a mass of unidentifiable particles in its digestive tract (marked by arrows). Abbreviations: av - anal fin; $\mathrm{cl}$ - cleithrum; pec-pectoral fin; pv - pelvic fin; vc - vertebral column. 

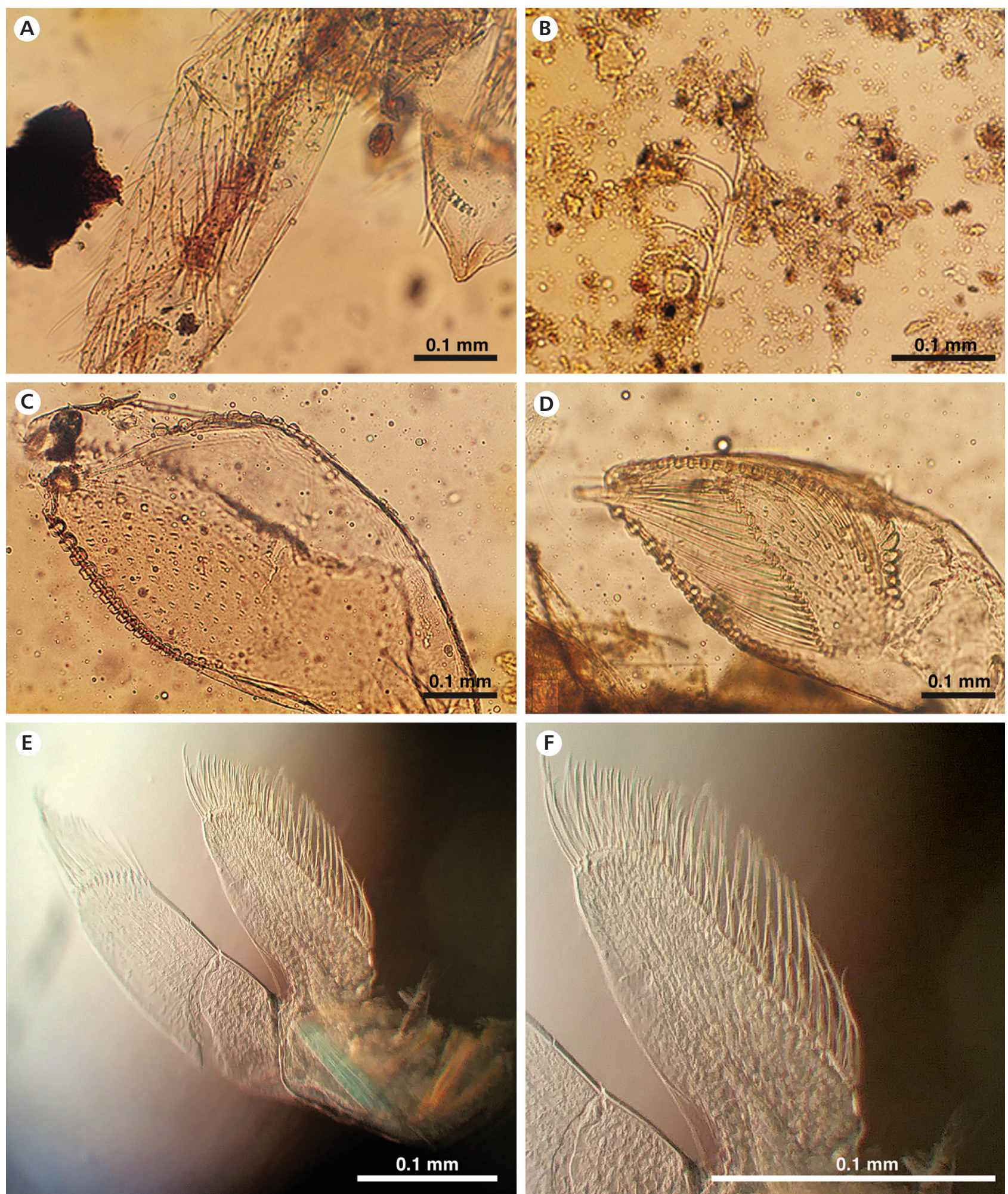

Figure 6. Arthropod remains within the digestive tract of Rhenanoperca minuta and similar structures in extant forms. $-\mathrm{A}-\mathrm{C}-$ Rhenanoperca minuta; A - presumed fragment of an amphipod leg, sample from HLMD 2003-3, specimen 41a, b, $26.04 \mathrm{~mm} \mathrm{Tl} \mathrm{(21} \mathrm{mm} \mathrm{Sl);} \mathrm{B} \mathrm{-} \mathrm{sensorial} \mathrm{sensilla} \mathrm{of}$ a crustacean, probably from a maxilla or labium, sample from HLMD-Me 171a, b, $43.4 \mathrm{~mm} \mathrm{Tl}(35 \mathrm{~mm} \mathrm{Sl})$; C - probable the inner part or endopodite of the left maxilla 1 of a gammarid shrimp, sample from HLMD 2003-3, specimen 41a, b, $26.04 \mathrm{~mm} \mathrm{Tl} \mathrm{(21} \mathrm{mm} \mathrm{S1).} \mathrm{D} \mathrm{-} \mathrm{detail} \mathrm{from} \mathrm{the} \mathrm{stomach}$ content of extant White bass, Morone chrysops, showing an almost identical structure, sample from HLMD-SMFR 31, $139.06 \mathrm{~mm}$ Tl (120.4 mm $\mathrm{Sl}$ ), transmitted and reflected light. • E, F - extant River-Niophargus, Gammarus roeseli Gervais, 1835, outer part of a maxilla, showing a similar morphological details; general view (E) and detail (F), transmitted light, Kinzig River, 2017. 

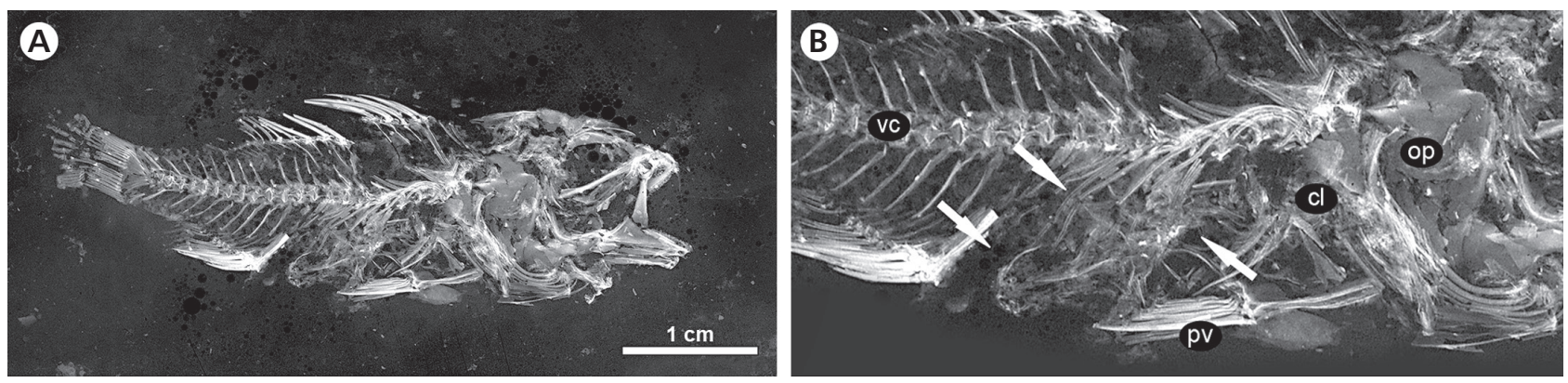

Figure 7. Rhenanoperca minuta, SMF-ME $675,33.10 \mathrm{~mm}$ Tl $(26.7 \mathrm{~mm} \mathrm{Sl})$. Radiograph of an individual with a smaller conspecific prey specimen in its digestive tract (marked by arrows); A - general view; B - detail with the skull of the predated fish in dorso-ventral view. Abbreviations: $\mathrm{cl}$ - cleithrum; op - opercle; pv - pelvic fin; vc - vertebral column.

mounted on micro-glass slides (3.4\%: HLMD-Me 13387; $42.45 \mathrm{~mm} \mathrm{Tl}, 35 \mathrm{~mm} \mathrm{Sl}$; c.t. Micklich 2012b) and in none of the nine samples of the non-prepared fresh individuals.

Cyclurus kehreri Andreae, 1893. - Here, it is a wellknown fact that the majority of the recorded specimens do not contain macroscopically identifiable prey remains, but have patches of a dark coaly mass in their abdominal cavities instead (Fig. 8A). Of the 15 samples in which the latter was investigated in greater detail, scale and some presumably eroded tooth fragments were repeatedly found (Fig. 8B), but it could in no instance be proven with certainty that they did not belong to the investigated specimen itself. Only in one sample $(6.7 \%$ : specimen HLMD 2006-3-15; $273 \mathrm{~mm} \mathrm{Tl,} 235 \mathrm{~mm} \mathrm{SL}$ ), one fragment could be identified as possibly belonging to the magistral trachea of an insect that was at least a couple of centimeters long (Fig. 8C).

Atractosteus messelensis Grande, 2010. - No food remains were found in the 12 respective samples.

\section{Pharyngeal jaw dentition}

Respective studies were only conducted in $R$. minuta. Herein, two different types clearly can be distinguished from one another. One is characterized by hypertrophied pharyngeal jaws with strong, flattened and roundish ("molariform") teeth (Fig. 9A-C), and the other has more delicate pharyngeal jaws with much smaller, elongate and slender ("papilliform") teeth (Fig. 9D). Representatives of the second type include specimens in which the delicate pharyngeal teeth are shorter and more conical and tapered in shape (Fig. 9E). Aside from these contradictory morphotypes, there also are individuals with intermediate types of pharyngeal dentition (e.g., SMF-ME 256, $44 \mathrm{~mm}$ $\mathrm{Tl}, 36 \mathrm{~mm}$ Sl respectively; Fig. 9F). The strong as well as the more delicate types both occur in comparatively small specimens of about $28-33 \mathrm{~mm}$ Tl (23-27 mm Sl; HLMD-
Me 12505, 15977 versus HLMD-Me 15193, SMF-ME 1436), while at least the molariform type (the papilliform one could not directly be proven here as these teeth are too tiny to be identified beneath the superimposing dermal bones) is also present in larger ones (HLMD-Me 14628; $74 \mathrm{~mm} \mathrm{Tl}, 60 \mathrm{~mm} \mathrm{Sl}$ ). As was already stated before, not very much can be said concerning the relative frequencies of the different types. During our fieldwork in 2104, e.g., a sample of 67 specimens was directly prepared according to the rapid transfer method. Of these, eight $(11.9 \%)$ had rather strong, pointed and conical teeth, and only two $(2.9 \%)$ exhibited the distinctively more delicate teeth of the same shape. None was found with the molariform type. Of the 54 specimens that are documented with radiographs, 23 (42.6\%) exhibited the strong molariform type of pharyngeal teeth, and only two (3.7\%) may have represented the alternative, more delicate type.

\section{Discussion and evaluation of the results}

\section{General significance of the sampling, preparation and investigation methods}

Fieldwork activities. - It is a matter of fact that during the excavations, small, incomplete, or otherwise imperfectly preserved specimens are significantly less often recovered and prepared for the museum collections. As a consequence, also the transfer-prepared specimens deposited in the latter probably are an underrepresentation of the "real" percentage of preserved contents of the digestive tracts in the fish assemblage of Messel Pit. This especially applies to species like Rhenanoperca minuta Gaudant \& Micklich, 1990 and Thaumaturus intermedius Weitzel, 1933, that a priori are represented by rather small-sized individuals. However, from another point of view, it also can be expected that individuals in which prey items that are clearly visible at the first glance (which usually means those projecting from the mouth) are recovered for the collection most of the times. Therefore, 

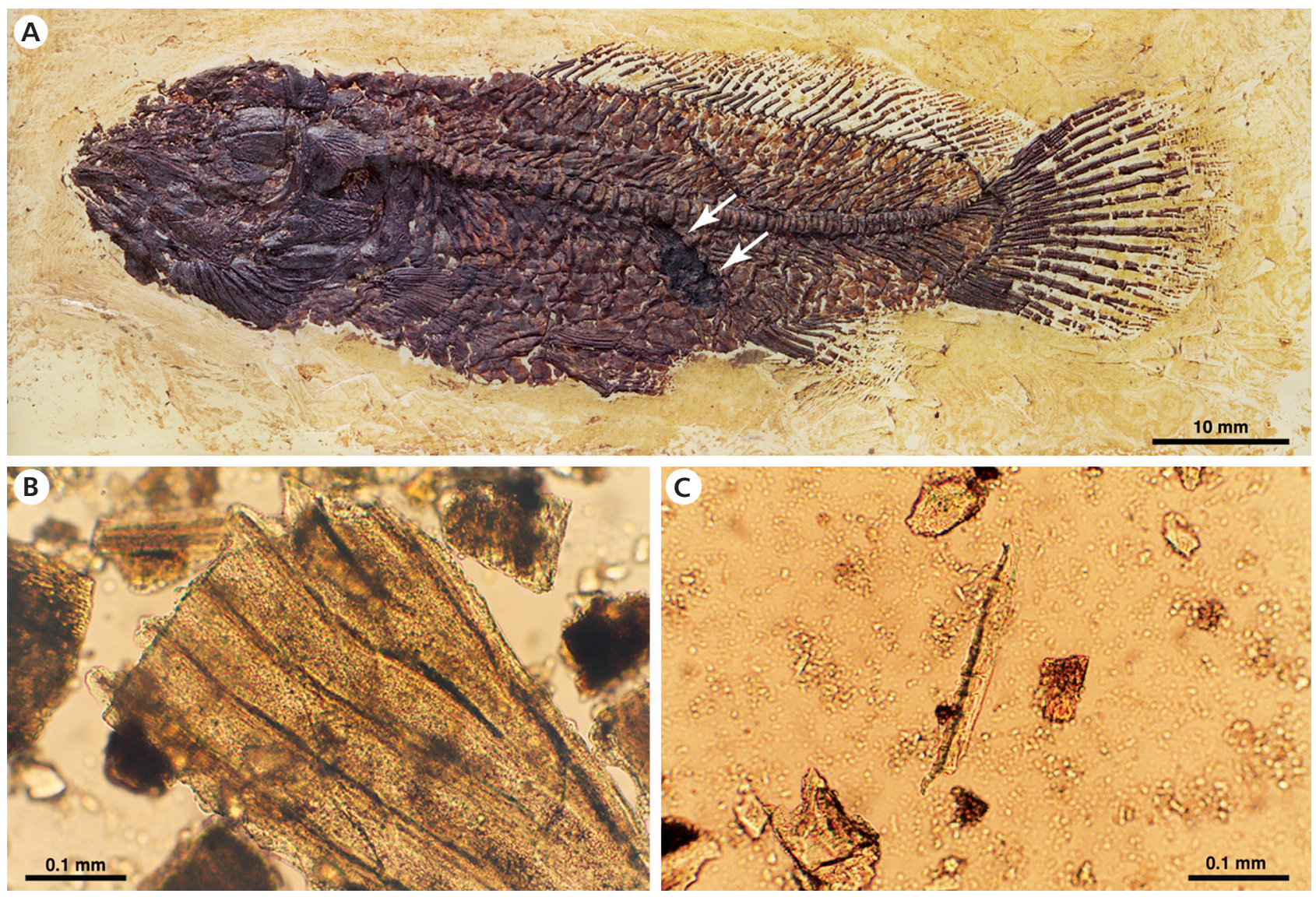

Figure 8. Cyclurus kehreri, contents of the digestive tract; A - HLMD-14958, $266.2 \mathrm{~mm} \mathrm{Tl} \mathrm{(230} \mathrm{mm} \mathrm{Sl).} \mathrm{Arrows} \mathrm{point} \mathrm{at} \mathrm{an} \mathrm{unstructured} \mathrm{coaly} \mathrm{mass}$ in the abdominal cavity; B - HLMD-Me 2006-3-211, $24.4 \mathrm{~mm}$ Tl $(210 \mathrm{~mm} \mathrm{S1})$. Unidentified scale fragment, probably from the same specimen rather than from a prey item; C - HLMD-2006-3-15, $235 \mathrm{~mm}$ Sl. Unidentified arthropod fragment, presumably of an insect's magistral trachea, as contents of the digestive tract.

the degree of underestimation in the end is likely not as high as originally feared. However, it is also true that prey fish and other forage items, especially tiny ones like arthropod remains, that are preserved within the digestive tract scarcely can be detected in those specimens that were "classically" transferred onto an artificial resin matrix.

Specimens transferred on micro-glass slides. - The situation is somewhat different concerning those specimens that were prepared according to this method. They were more or less randomly sampled, discarding only those that were too large to fit on the latter. They can be examined under reflected and transmitted light under a binocular or, if needed, at even higher magnification, under a microscope. Therefore, it is in principle possible to detect smaller prey items like arthropods in those samples (see Micklich 2012b). The major disadvantage is that the fossil substance is rather dark, so that underlying lighter and more delicate forage food items may be obscured.

Targeted withdrawal of materials from the area of the gastro-intestinal tract. - This problem is resolved when such small samples are extracted from fresh, nonprepared specimens that are bleached and also mounted on micro-glass slides for further study. Even those from larger specimens can be examined this way, and possible contents of the digestive tract will not be obscured by the substance of the predator itself. This means that there definitely is an option to detect and identify prey items other than fish. Unfortunately, when using this method, articulated prey fishes that originally may have been preserved inside the predator, usually are broken up into small fragments and scarcely can be identified as such. As a result, aside from the latter remains, mainly displaced pharyngeal teeth can be detected in this manner.

Radiographs. - Complete specimens that are documented and investigated this way undoubtedly provide an excellent opportunity for detecting prey fishes or respective remains within the digestive tract. Nevertheless, in many cases, such prey items will already be visible when preliminarily investigating these specimens under a binocular. In addition, radiographs hardly are suitable for providing evidence of insect or other arthropod remains. They will 

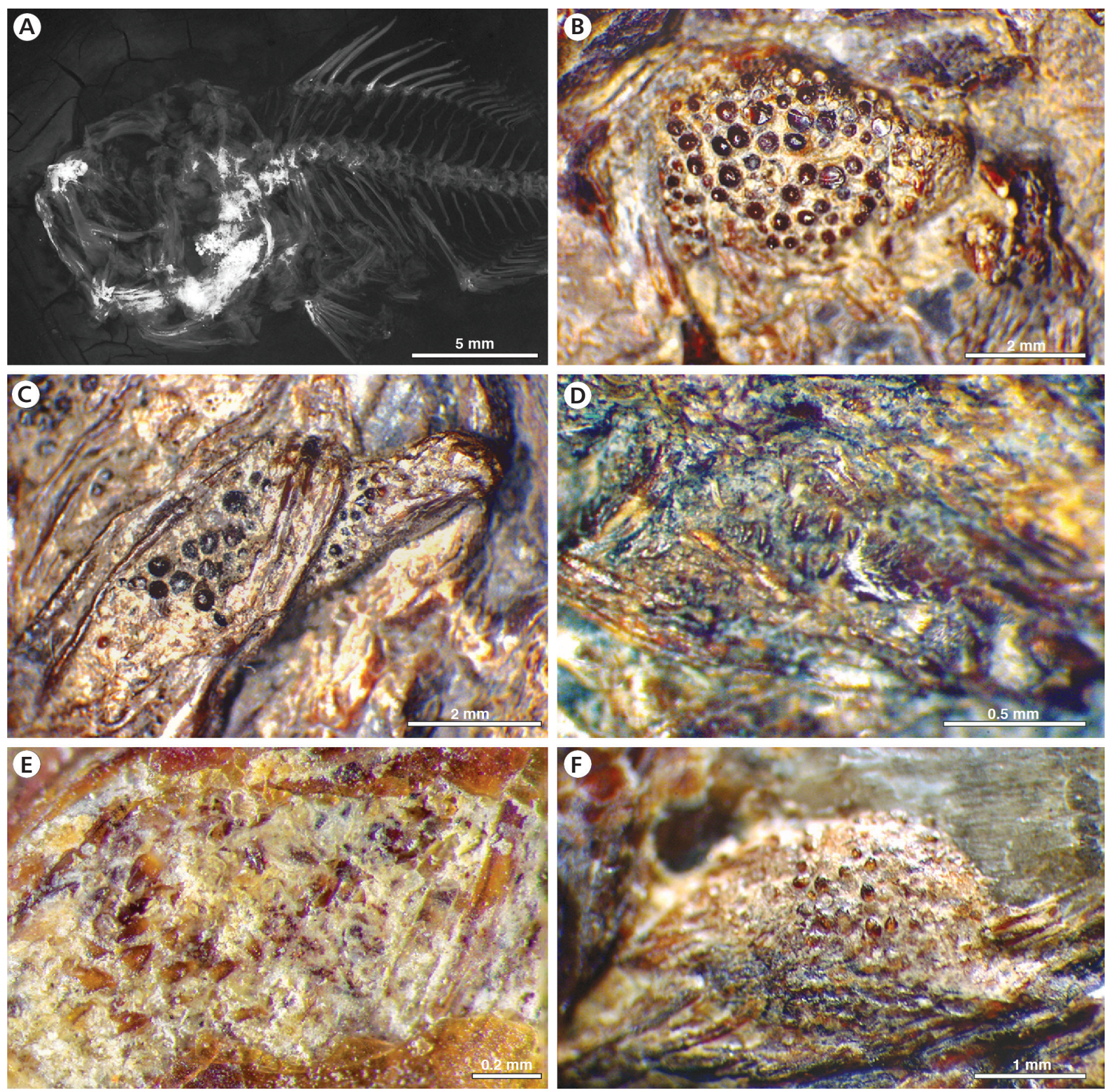

Figure 9. Rhenanoperca minuta, different types of pharyngeal dentition; A - radiograph of the head and anterior body portion of a specimen with strong, obviously non-fused lower pharyngeal jaws bearing "molariform" teeth, SMF-ME 174a, $45.71 \mathrm{~mm} \mathrm{Tl} \mathrm{(36.87} \mathrm{mm} \mathrm{Sl);} \mathrm{B} \mathrm{-} \mathrm{same,} \mathrm{detail} \mathrm{of} \mathrm{the}$ upper pharyngeal jaw, SMF-ME 1432, $178.2 \mathrm{~mm} \mathrm{Nl}$; C - same, detail of the lower pharyngeal jaws, HLMD-Me 15839, $58.9 \mathrm{~mm} \mathrm{Tl}$ (47.5 mm Sl); D - detail of the upper pharyngeal jaw with delicate and slender ("papilliform") teeth, SMF-Me 1436, $34.59 \mathrm{~mm} \mathrm{Tl} \mathrm{(27.9} \mathrm{mm} \mathrm{Sl);} \mathrm{E} \mathrm{-} \mathrm{same,} \mathrm{detail,}$ predominantly of the lower pharyngeal jaws with delicate, but shorter and more conical pharyngeal teeth, HLMD-Me $15193,27.44 \mathrm{~mm} \mathrm{Tl}(22.13 \mathrm{~mm}$ $\mathrm{Sl})$; F - same, detail of the lower pharyngeal jaws with an intermediate type of pharyngeal dentition, SMF-ME 256, $44.28 \mathrm{~mm} \mathrm{Sl} \mathrm{(35.71} \mathrm{mm} \mathrm{Sl).} \mathrm{Except}$ A, the tip of the snout always points to the left.

also not be significant from a statistical point of view either, as they are not normally taken at random, but usually limited to some well-preserved and attractive specimens.

All in all, and aside from some minor disadvantages, random samples from non-prepared fresh materials provide the best chances of detecting arthropod remains within the digestive tract of Messel fishes, whereas complete specimens that either are transferred onto an artificial resin matrix or micro-glass slides will be better suited for the detection of larger prey items, such as articulated prey fish remains.

With regard to our investigations of the pharyngeal dentition, teeth may get lost by splitting off the oil shale 


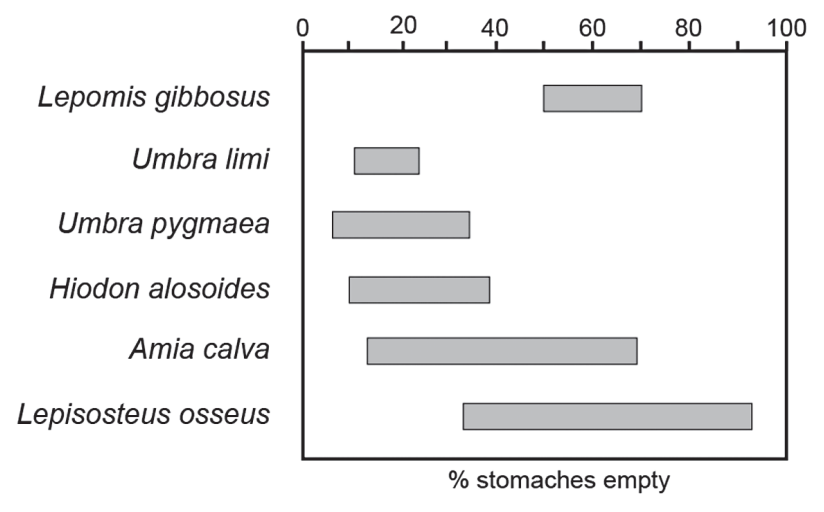

Figure 10. Average rates of empty stomachs in comparative extant species. Pumpkinseed, Lepomis gibbosus (Linnaeus, 1758), data from Zapata \& Granado-Lorenzino (1933). Central mudminnow, Umbra limi (Kirtland, 1840), data from Peckham \& Dineen (1957) as well as from Kofron \& Schreiber (1983). Eastern mudminnow, Umbra pygmaea (DeKay, 1842), data from Lombardi (2009) as well as from Panek \& Weis (2013). Goldeye, Hiodon alosoides (Rafinesque, 1819), data from Donald \& Kooyman (1977) as well as from Moon et al. (1998). Bowfin, Amia calva, Linnaeus, 1766, data from Lagler \& Hubbs (1940), Lagler \& Applegate (1942), Diana (1966), Dugas et al. (1976), Lagler \& Watts (2004) as well as from Nawrocki et al. (2016). Longnose gar, Lepisosteus osseus (Linnaeus, 1758), data from Smylie et al. (2015). For other gar species, rates up to $82 \%$ of empty stomachs were reported, e.g., by Tyler \& Granger (1984).

during fieldwork. They may also be inadvertently removed when clearing one side of the fossil before transfer preparation. Even in such specimens, the pharyngeal jaws are often concealed under superimposed elements, like the opercles, and can only be seen in a few specimens. If they are preserved, the best way to look at them is in radiographs. This method is largely restricted to the more robust types of teeth, however, whereas the others are too small and thus are difficult to detect even in microradiographs or CT scans. Therefore, the best way to record them is by means of the rapid transfer preparation method right during fieldwork, but even then success is of course still left to chance.

\section{Special aspects of the results}

\section{Evacuated digestive tracts}

In extant fishes, digestion rates, or better to say gut evacuation rates, considerably differ between species (Tseitlin 1980). They furthermore depend on a variety of factors, e.g., temperature, body size, size and type of the meal, feeding frequency, diurnal, seasonal and/or annual fluctuations in the availability of food, as well as individual cycles of feeding activities (e.g., Molnár et al. 1967, Langton 1977, Smith 1980).

When looking at extant species that either are closely related to the Messel ones, or that can be considered in a way as ecological equivalents, it is evident that these (at least in part) have distinctly lower gastric evacuation rates than the Messel forms (Fig. 10). Furthermore, there are considerable local, seasonal, and annual differences and fluctuations (Fig. 11). In particular outstanding is the presence of almost completely evacuated gastric tracts of certain species during certain periods of time as well as, in contrast to this, that in other species the stomachs are almost completely full during other seasons. As a consequence, the relative number of specimens with evacuated digestive tracts can vary in the same way, and there may be evacuation peaks at certain times of the day or the season (see also Keast \& Welsh 1968, Craig 2000).

Published information concerning the relative values of evacuated digestive tracts in Messel fishes is only available for R. minuta and T. intermedius (Fig. 12). Both species fall distinctly (to about one tenth) below the values those were reported in the literature (Richter \& Baszio 2001b, 2006). Looking at possible explanations, these differences scarcely can be referred to different methodologies, especially not for those samples that were directly taken from fresh and non-prepared fossils. First of all, arthropod remains are numerous, well preserved, and clearly identifiable in the respective samples from the extant reference species investigated herein, although these were treated with almost the same preparation methods as the fossils. In addition, arthropod remains can also be identified in a few of the fossil samples of the present study. We therefore have to look for other explanations.

Richter \& Baszio (2001a), Richter \& Wedmann (2005), as well as Richter et al. (2017), stated that significant changes occurred in the composition of the microfauna and -flora during the history of Lake Messel. Only the larvae and pupae of phantom midges (Chaoboridae) were more or less evenly distributed over the whole Middle Messel Formation and therefore principally should also be available for the individuals of $R$. minuta and $T$. intermedius. The majority of the investigations by Richter and his co-authors refer to larger profile sections and are mainly based on isolated coprolites. Short-term changes of the palaeoenvironmental conditions and thus, possibly, also in the feeding resources of the Messel fish species, were indicated by the analyses of the microstratigraphical fish distribution patterns by Micklich (2012a). When, e.g., plotting the vertical fish distribution pattern against those of the insect and plant remains, it becomes evident that there may have been temporary deficiency situations. Not in all layers with $R$. minuta was there a sufficient availability of arthropods and, similarly, not in all layers with larger predatory fish, like C. kehreri, was there a sufficient availability of smaller prey fish like $R$. minuta and/or T. intermedius (Fig. 13). The differences between the former and the present studies may therefore result 


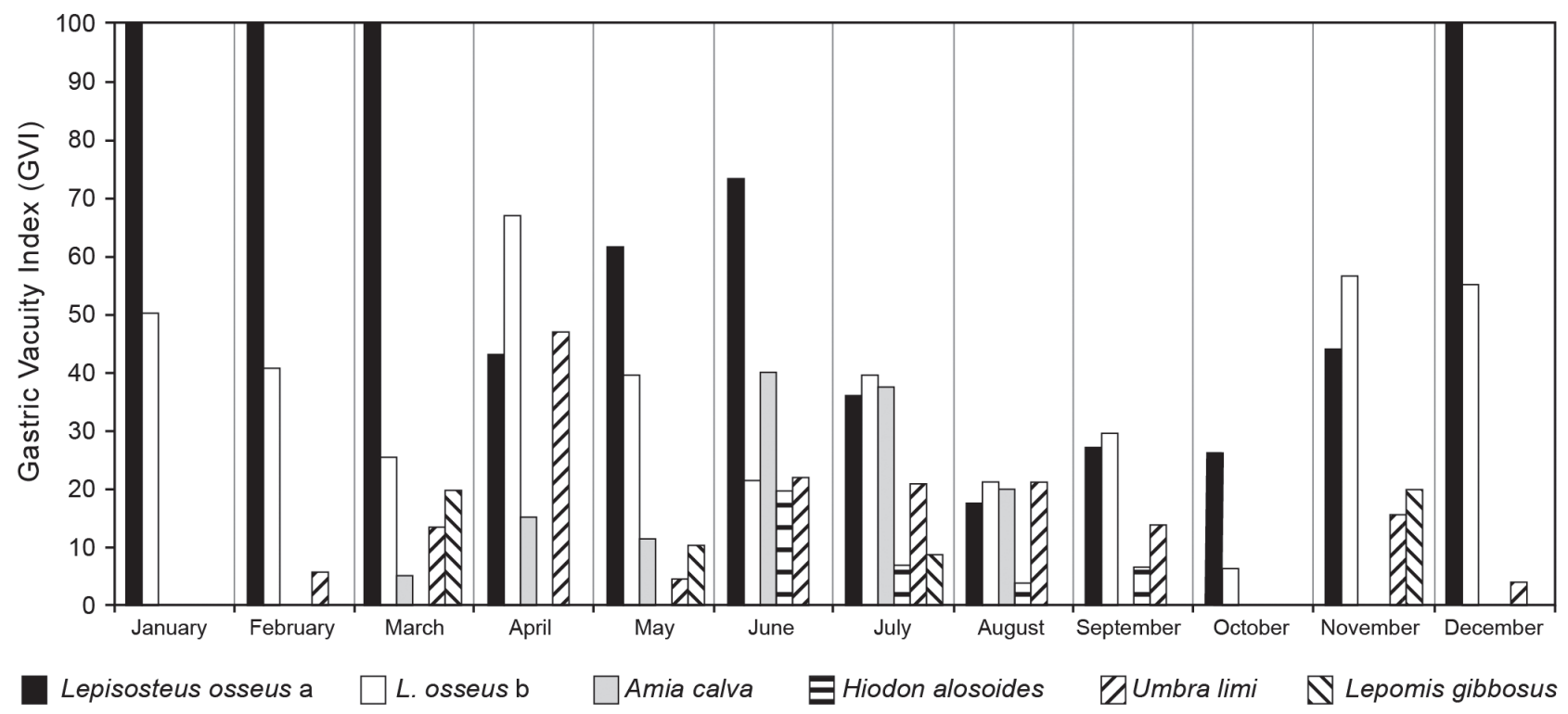

Figure11. Seasonal variation of the gastric vacuity index in comparative extant species. Lepisosteus osseus - data from McGrath et al. (2013); Amia calva - data from Berry (1955); Hiodon alosoides - data from Donald \& Kooyman (1977); Umbra limi - data from Peckham \& Dineen (1957); Lepomis gibbosus - data from Nikolova et al. (2008). Hiodon alosoides - no empty stomachs during October; Umbra limi - no empty stomachs in January. Otherwise, no data were available for the respective species for those months that are without bars.

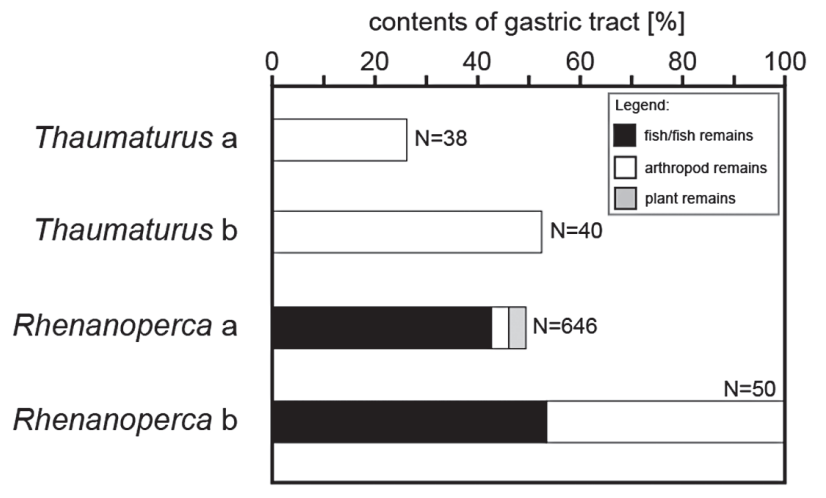

Figure 12. Comparison of the digestive tract contents of Thaumaturus intermedius and Rhenanoperca minuta with published information. Thaumaturus a - present study, combined data from micro-glass slide and direct samples (value $\times 10$ for improved readability); Thaumaturus b - data from Richter \& Baszio (2001a, b); Rhenanoperca $\mathrm{a}$ - combined data from transfer-prepared specimens, specimens on micro-glass slides, radiographs and direct samples (value $\times 10$ for improved readability); Rhenanoperca $\mathrm{b}$ - data from Richter \& Baszio (2006).

from different (micro-) stratigraphical positions of the samplings. At least concerning R. minuta, the samples that were referred to by Richter \& Baszio (2006) were collected from slightly different oil shale sections than those referred to in the present study (from -49 to $+70 \mathrm{~cm}$ below/above reference layer $\gamma$ ), and thus really may differ for such reasons.

It furthermore could be argued that the preservational conditions for arthropod remains in such coprolites may differ from those inside the digestive tracts of dead fishes during the process of fossilisation. Richter et al. (2017) indeed supposed that certain fossilisation details may have essentially contributed to the perfect preservation of arthropod remains in coprolites. If at all, this may refer mainly to small remains rather and not to larger and more solid ones like that of articulated prey fishes.

Unfortunately, this altogether still does not resolve the dilemma: (1) why does the relative number of evacuated digestive tracts of Messel fish species in the present study distinctly exceed that of former investigations? (2) What is the reason for the scarcity of arthropod remains? And (3) why are these remains (phantom midges and mosquitoes versus malacostracan crustaceans, respectively amphipod remains) different from those found in $R$. minuta and T. intermedius before? Presently, there is not a truly satisfactory explanation for these differences.

Even more difficult to understand is the extremely high percentage of empty digestive tracts in the Messel bowfins and gars, especially as this is in strong contrast to closely related species from other fossil localities, which comparatively often are preserved with prey fish in their mouths or as stomach contents (e.g., Grande 2013). Theoretically, the rate of evacuated digestive tracts in these Messel fish species may have been rather complete as a result of comparatively high temperatures (mean annual temperature approximately $22{ }^{\circ} \mathrm{C}$, according to Grein et al. 2011), and the fishes may have died at a time when their digestion was complete or at least at a rather advanced stage. But according to Herting \& Witt (1968), 

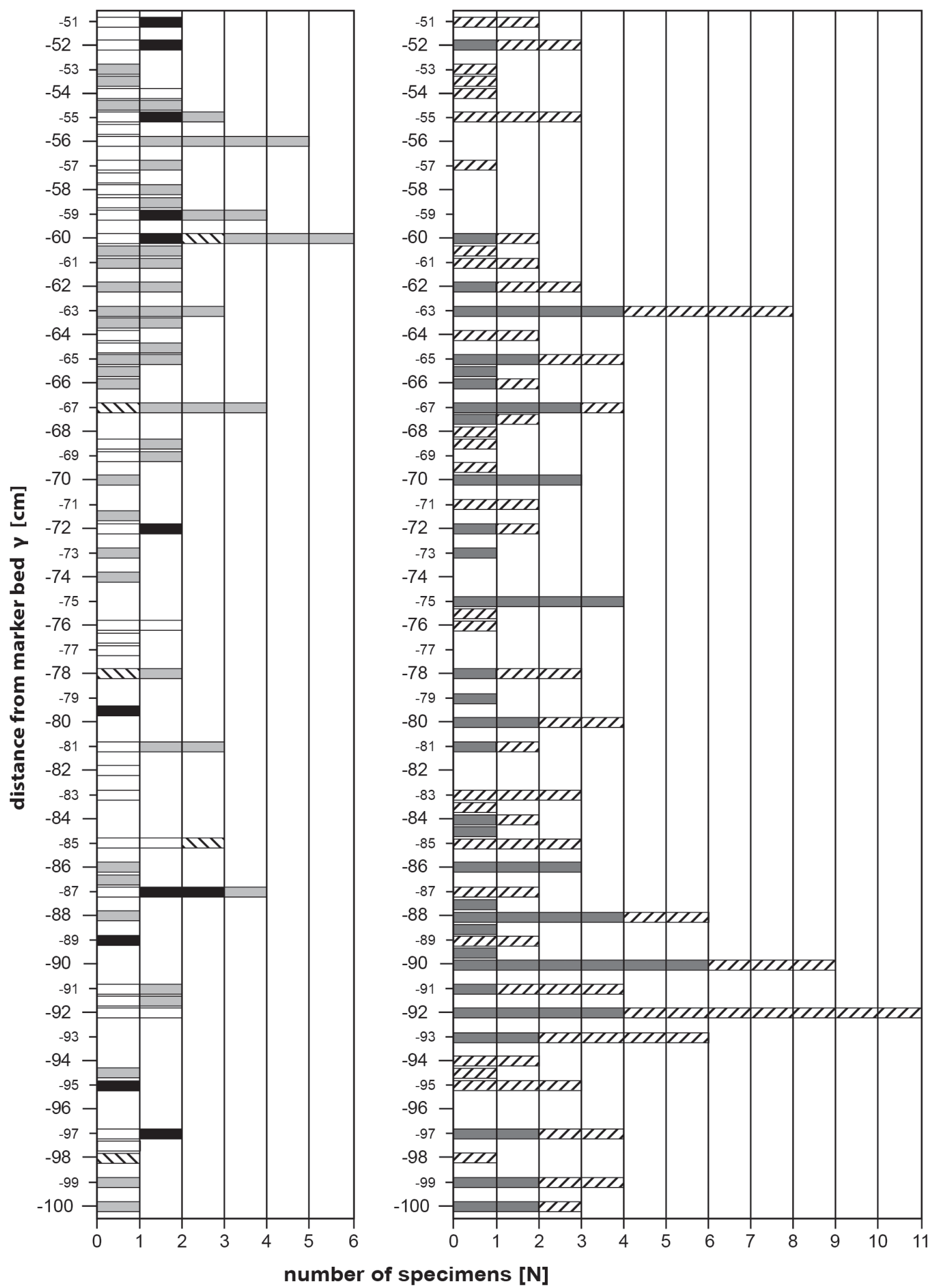

A

number of specimens [N]

Atractosteus $\square$ Cyclurus $\triangle$ Palaeoperca

Rhenanoperca

insect remains

$\square$ arthropod remains

Figure 13. Microstratigraphical fish distribution pattern in the range of reference layer $\gamma$ during the Messel excavations of HLMD between 1996-2006 (modified from Micklich 2012a). Only those records that were precisely measured in the profile, were taken into consideration. Left-hand side (A) fishes; Right-hand side (B) - insects, insect and arthropod remains, respectively. 
Hunt (1960) and Netsch \& Witt (1962), in comparative extant species, and even at a similar temperature range, the time required for completely digesting a meal is rather long (A. calva Linnaeus, 1766, 28-32 hours at $21{ }^{\circ} \mathrm{C}$; L. osseus (Linnaeus, 1758), 24 hours at $26.4{ }^{\circ} \mathrm{C}$; Lepisosteus platyrhincus DeKay, 1842, 24-25 hours at $24-25^{\circ} \mathrm{C}$ ). Aside from $R$. minuta, as a species that at least predominantly seems to have been specialised on a gastropod-dominated diet (see section "Development of the pharyngeal dentition"), suitable prey items should have been available to a sufficient extent to all other Messel fish species considered herein. Extant Bowfin (A. calva) and extant Shortnose gar (L. osseus) switch from an arthropod-dominated diet when reaching $70-100 \mathrm{~mm} \mathrm{Tl}(60-86 \mathrm{~mm} \mathrm{Sl})$ and $20-50 \mathrm{~mm} \mathrm{Tl}$ (18-44 mm Sl), respectively (Mittelbach \& Persson 1998). This suggests that the specimens that make up the mass of Messel records already should have been piscivorous. This also means that, aside the temporary deficiency situations mentioned before, suitable prey fishes (like $R$. minuta or T. intermedius) for them principally should have been available in those profile sections, from which the specimens, respectively samples, of the present study were recovered from (Micklich 2012a). And theoretically it is just the same with regard to the arthropods that should be suitable prey items for R. minuta and T. intermedius (Micklich 2012a, Richter et al. 2017). Even C. kehreri, that, according to its vomerine and coronoid dentition may also have been somewhat specialised in preying on hardshelled items (Grande \& Bemis 1998), definitely should also have been able to prey on other fish (see Micklich 2007, 2012a) if their preferred prey items were not available in sufficient quantities. Artefacts due to preservation can also be discarded because of the generally excellent fossilisation conditions at Lake Messel.

Which explanation is left after all? For R. minuta and $T$. intermedius, it may be the microstratigraphical differences in the origin of those samples that were taken in the past and the present study, in combination with short-term changes in the environmental conditions, and a scarcity of suitable prey, at least in R. minuta. Generally, prey items may also have been regurgitated during death throes (Lambou 1962), either because of hostile environmental conditions (Micklich 1985, Micklich \& Mentges 2012) or for other reasons (e.g., parasite infestations; North American Native Fish Association 2015). This hardly can have taken place in the wide range of all excavated oil shale layers, however. The most probable explanation for the bowfins and gars may therefore be to ascribe these peculiarities to diurnal or, more probable, seasonal fluctuations in their general activity and feeding cycles, respectively. Unfortunately, such effects cannot be checked in detail here for practical reasons: it is possible to define the microstratigraphical positions of most fish records during fieldwork, but not to relate their moment of death to a certain period of the day, season, or year.

\section{Diet switch in Rhenanoperca minuta}

A change in dietary predilections will take place at a welldefined stage of growth in many extant predatory fish species, but there also are fish species that do not switch from one type of food to another at all, or at least not in a more or less sudden event but in a phase of gradual transition (e.g., Gerkin 1994, Mittelbach et al. 1999). Nevertheless, and similar to the factors affecting the rate of gastric digestion, this time of switching from invertebrates to fish in piscivorous species is a widely variable feature, depending on numerous individual and external limitations (e.g., Keast \& Welsh 1968, Gerkin 1994, Mittelbach \& Persson 1998). Concerning percomorphs, the Smallmouth bass, Micropterus dolomieu Lacépède, 1802, which can reach $70 \mathrm{~cm} \mathrm{Tl}$, starts to feed on fish as early as at $12 \mathrm{~mm} \mathrm{Tl}$ (Carlander 1977), whereas in slow-growing populations of the European river perch, Perca fluviatilis Linnaeus, 1758, which can reach about the same maximum $\mathrm{Tl}$, first prey fish are consumed as late as at $130-150 \mathrm{~mm} \mathrm{Tl}$ (Laskar 1942, Craig 2000).

Looking at those extant species that can be regarded as ecological equivalents of $R$. minuta and switch to a fishdominated diet during ontogeny, this gradually starts to play a role at $50-99 \mathrm{~mm} \mathrm{Tl}$ in the Green sunfish, L. cyanellus Rafinesque, 1819 (Sadzikowsi \& Wallace 1976). Once again, depending on locality and availability, fish finally can constitute up to $10-65 \%$ of their diet (Mittelbach \& Persson 1998). Likewise, in the Black crappie, Pomoxis nigromaculatus (Lesueur, 1829), fish become of increasing importance in larger specimens (at 161-200 mm Tl; Keast 1968).

Richter \& Baszio (2006) concluded that $R$. minuta switched from feeding primarily on planktonic arthropods (predominantly chaoborid and culicid larvae) to fish at $30 \mathrm{~mm} \mathrm{Tl}$ and that very small individuals of T. intermedius became the most important food resource after that dietary switch. In contrast, all past studies (e.g., Micklich 1985 ) and also the present one demonstrate that $R$. minuta was cannibalistic over a comparatively wide size range (at least from 25 to $74 \mathrm{~mm} \mathrm{Tl}, 20-60 \mathrm{~mm} \mathrm{Sl}$, respectively) rather than feeding on $T$. intermedius. This is furthermore supported by the following facts: firstly, the latter species is extremely rare in those oil shale sections that are dominated by $R$. minuta ("Turtle Hill", grid square HI 7, reference layer $\gamma$ : Micklich 2012a). Secondly, if it really was the main prey, articulated individuals or remains should have been found at least occasionally in the mouths or digestive tracts of $R$. minuta as is the 

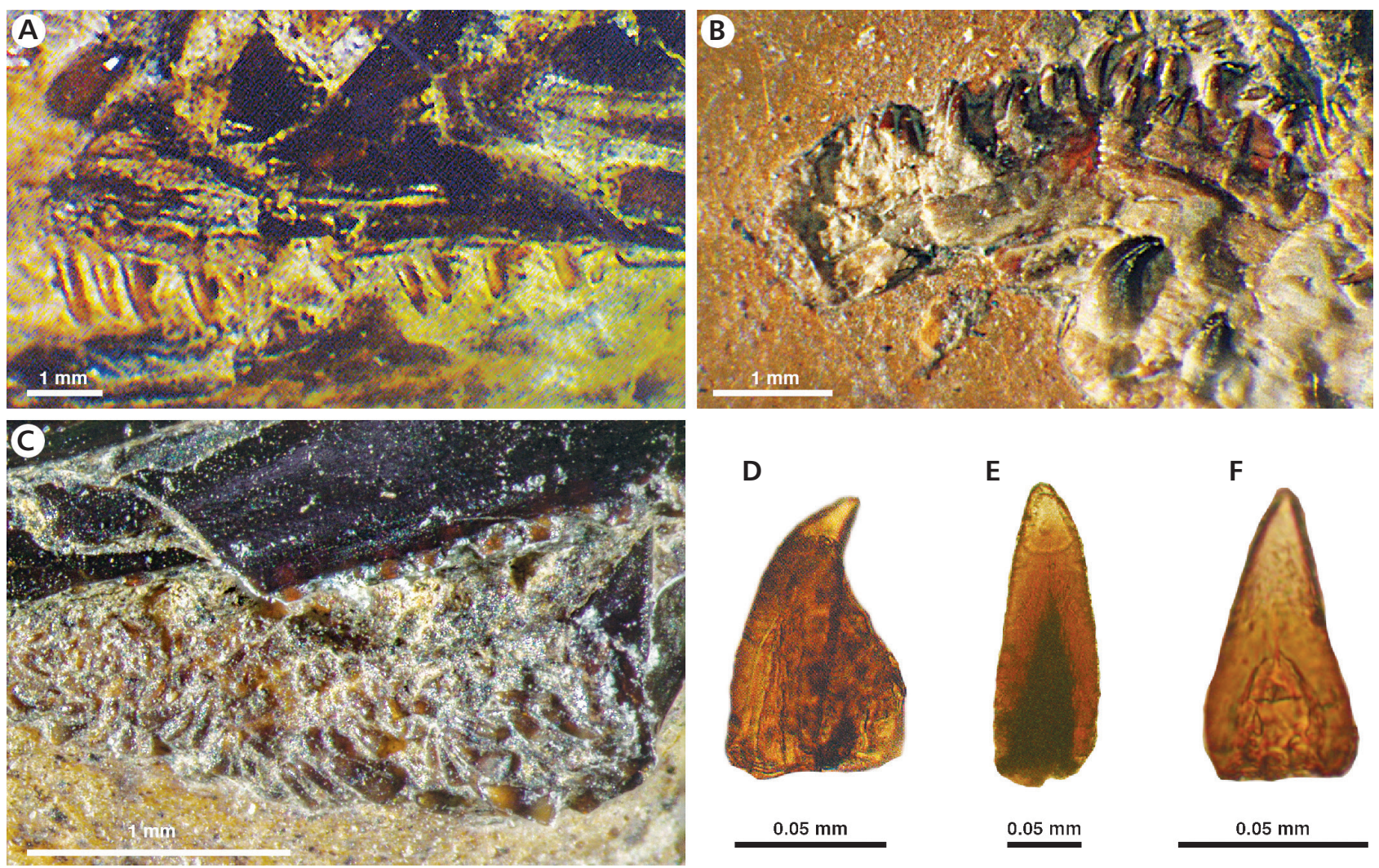

Figure 14. Comparison of the oral and pharyngeal jaw dentition. • A, B - Thaumaturus intermedius; A - detail of straight to slightly curved teeth from the premaxilla, SMF-ME 2283, $71.41 \mathrm{~mm}$ Tl $(62.20 \mathrm{~mm} \mathrm{Sl})$, scale bar $1 \mathrm{~mm}$, tip of the snout pointing left; B - same, curved and partly massive teeth from the basihyal, SMF-ME 1054a, $69.77 \mathrm{~mm} \mathrm{Tl}(58 \mathrm{~mm} \mathrm{Sl})$, scale bar $1 \mathrm{~mm}$, tip of the snout pointing left. $\cdot \mathrm{C}-\mathrm{F}-$ Rhenanoperca minuta; C - detail of the premaxillar dentition, HLMD-Me 10486, $59.40 \mathrm{~mm} \mathrm{Tl}(47.92 \mathrm{~mm} \mathrm{Sl})$, scale bar 1 mm, tip of the snout pointing right; D-F - same, pharyngeal teeth from non-prepared specimens that resemble those that were figured by Richter \& Baszio (2006, figs 5, 6, 13) as being typical of Thaumaturus, (D, E) - HLMD-Me 2005-3-238, $2.87 \mathrm{~mm} \mathrm{Tl}(2.32 \mathrm{~mm} \mathrm{Sl})$, (F) - HLMD-Me 367, $3.08 \mathrm{~mm}$ estimated Tl (2.48 Sl).

case in cannibalized specimens of the latter species. And thirdly, those teeth that were figured by Richter \& Baszio (2006) as being typical of $T$. intermedius resemble certain pharyngeal (and also oral) teeth of $R$. minuta (Fig. 14). Curved teeth with a pointed tip that is set posteriorly at an oblique angle differ from those of the premaxilla as well as of the basihyal tooth plate of Thaumaturus (Fig. 14A, B), which are at least evenly curved along their longitudinal axis. Therefore, they may just as well have been displaced posteriorly from the oral and/or pharyngeal jaws of the predator itself or represent remains of ingested conspecific individuals. The presumed tooth of $T$. intermedius of their fig. 5, e.g., is almost identical with the pharyngeal tooth of the latter species that is figured in 14D herein. Piscivory in larger R. minuta individuals furthermore contradicts the morphology and dentition of the pharyngeal jaws (see section "Development of the pharyngeal dentition"). This means that a dietary shift in $R$. minuta, if there was any, should have happened from soft-bodied arthropods to hard-shelled prey (most likely gastropods) rather than from soft-bodied invertebrates to fish.
Irrespective of the different results concerning the kind of prey that was preferred by larger individuals of this species (Richter et al. 2017 versus this study), a diet switch (if there was any) in $R$. minuta seems to have occurred rather early (at 25-29 $\mathrm{mm} \mathrm{Tl}, 20-24 \mathrm{~mm} \mathrm{Sl}$, respectively), at least distinctly earlier than in any of the comparative extant species referred to before. Of these, all individuals grow distinctly larger than the largest records of the Messel one. According to Carlander (1977), the Green sunfish can reach $300 \mathrm{~mm}$ in maximum Tl, (with 31-91 $\mathrm{mm}$ at the first year of life), and the Black crappie $490 \mathrm{~mm}$ (with $36-141 \mathrm{~mm} \mathrm{Tl}$ at the first year). Therefore, only the size ranges within the first age class are similar to $R$. minuta. This is in good correspondence to the result of age and growth studies that demonstrated that the mass of the respective individuals in this species are young-ofthe-year (Micklich 2002). In extant fish species, growth rates of such young fishes will dramatically increase after they have switched to feeding on fish, and species that become piscivorous during their first summer will have grown substantially larger at age one and during all subsequent stages than others that switch later in life 
(Mittelbach \& Persson 1998). By contrast, in R. minuta from Messel, no individual has so far become known that is larger than $92 \mathrm{~mm} \mathrm{Tl}(74 \mathrm{~mm} \mathrm{Sl})$ with the majority of specimens measuring less than $39 \mathrm{~mm} \mathrm{Tl}(35 \mathrm{~mm} \mathrm{Sl})$. This is, in principle, highly indicative of a habitat segregation, where the full-sized and sexually mature individuals mainly lived outside the lake and either temporarily entered the lake during the breeding season or, more probably, only juveniles entered or were washed into the lake. In combination with the fact that the prey of $R$. minuta predominantly consists of smaller conspecific individuals, this once more suggests very specific habitat and behavioral conditions.

\section{Cannibalism}

This is a well-known phenomenon in many teleostean fishes. It occurs in 26 of 410 families, but probably is even more widespread in a wide variety of taxa and associated with different habitats and with different life strategies (Smith \& Reay 1991). Generally, it is a response to conditions of low food availability and/ or quality, but is also recorded from seemingly wellprovided fish. Cannibalism is important for controlling population densities in freshwater fishes as it reduces very high population densities (Goldspink \& Goodwin 1979, Smith \& Reay 1991, Gerkin 1994, Craig 2000). It may be the main cause of mortality in certain age and size classes (Carlander 1997).

In $R$. minuta, the cannibalistic behavior very probably can be classified as of an intracohort type that is one that takes place between larger and smaller individuals of the same age. Furthermore, it was of a non-kin type, which means, that aside from their being conspecific, predators and prey were not more closely related to each other (Smith \& Reay 1991). Finally, it may have resulted from an emergency situation, like the "classic" scenarios that will trigger cannibalism in extant fish populations. There may have been a general shortage of suitable prey for a "shell-cracker" like R. minuta within the Messel fossil record: shrimps are known from a few specimens only and remains of snails also are comparatively scarce, especially in those layers that are dominated by $R$. minuta. In addition, viviparoids, which are the most abundant type of snails in Messel, are up to $15 \mathrm{~mm}$ in maximum height (Neubert 1999), and the shrimps are about $22-35 \mathrm{~mm}$ in body length (Micklich 2007). Therefore, they may have been too large as prey for the majority of the small-sized individuals of $R$. minuta. They principally may have been inside the prey size range of the larger individuals (e.g., HLMD-Me 15836, SMF-ME 990), but respective remains (like opercular or radular fragments of which at least the latter should principally be suited for preservation as they consist of chitin) were not recorded even in the "fresh" study materials. Nevertheless, there may have been a sufficient overall food availability (at least, culicid and chaoborid larvae and pupae; Richter et al. 2017) for the smaller individuals of $R$. minuta before they switched to a diet of gastropods. Therefore, at least for a period of time, the living conditions for these individuals may have been optimal. When conditions worsened, the cannibalistic individuals simply preyed upon the most abundant kind of food (Micklich 1992). The originally high population density may have led to a scarcity of suitable soft-bodied prey later on, a deficiency situation, which resulted in an early onset of cannibalism. This, however, is only common in extant piscivores (Smith \& Reay 1991), but not very much has been reported for species that switch to gastropods as it is indicated by the molariform pharyngeal dentition of most specimens of $R$. minuta. Only for the Midas cichlid, Amphilophus citrinellus (Günther, 1864), a species that switches to gastropods at larger body sizes, it is known that the fry will feed on small substrate invertebrates, and also are cannibalistic (Gottfried 1986).

\section{Size of prey}

The size and also the type of prey consumed by teleostean fishes is limited by the predator's gape size and throat width with respect to body depth/particle size (Juanes et al. 2002). Many fish will feed on the largest prey organisms they are able to ingest (Carlander 1977, George \& Hadley 1979). The optimal ratio between the prey size (as defined by the diameter of the narrowest axis) and the mouth size of the predator is about 0.59 (Werner 1974). There is a wide variation in the prey size range of some extant piscivorous percomorphs. Individuals of the Striped bass, Morone saxatilis (Walbaum, 1792), e.g., feed on prey that is $46.1 \%$ of their own length when they are about $16 \mathrm{~mm}$ in $\mathrm{Tl}$, and of $53.3 \%$ when they are $19 \mathrm{~mm} \mathrm{Tl}$. In contrast, Warmouth, Lepomis gulosus (Cuvier, 1829) of the same $\mathrm{Tl}(19 \mathrm{~mm})$, will ingest fry that are only about $26 \%$ of their own length (Carlander 1977).

In those specimens that were preserved with articulated prey, the latter has a range between 28 and $70 \%$ of the predator's length in R. minuta. Thus it clearly exceeds the one that is reported for many extant species. Interestingly, the comparatively largest percentage was found in a rather small individual (HLMD-Me 15837) of about $25 \mathrm{~mm} \mathrm{Tl}(20 \mathrm{~mm} \mathrm{Sl})$. This is somewhat in contrast to many extant forms, in which the length of the prey fishes increases with increasing length of the predator (Carlander 1977). Nevertheless, R. minuta is characterised by a comparatively large head (Gaudant $\&$ Micklich 1990) and, therefore, should have been able to ingest fish or other larger prey already at a comparatively small size. Furthermore, in some extant predators with cannibalistic tendencies the prey sometimes is larger than in those 
with no cannibalistic disposition (Juanes 2003). The size of the prey consumed also largely depends on the relative predator and prey mobility. In confined areas with limited prey escape options, predators usually are able to consume prey whose size will be close to the limitations of their gape, whilst in more open areas with various options for the prey to escape or hide away, the size of the prey consumed will be considerably smaller (Juanes et al. 2002). The large size range of the prey in $R$. minuta also may therefore result from environmental restrictions in combination with morphological options (large head) and cannibalism.

\section{Development of the pharyngeal dentition}

Strong, massive and blunt pharyngeal teeth, like those found in many individuals of $R$. minuta, are typical of extant "shell cracker" species, whilst another type, which consists of more delicate, pointed teeth like those also found in some individuals of this species, is mainly typical of extant insect or detritus feeders (Greenwood 1972, Barel et al. 1977, Liem 1979). In many extant percomorphs, there is an ontogenetic dietary shift from softbodied invertebrates to gastropods and this shift is clearly correlated with a morphological transition from one type of pharyngeal strength and dentition to the other. This typically happens in the Pumpkinseed, L. gibbosus, in which adult individuals are trophic specialists feeding on gastropods, which they crush with their pharyngeal jaws (Wainwright et al. 1991). Nevertheless, the preference for gastropods is highly dependent on their availability and may change, or markedly differ in different habitats and even in populations (Mittelbach et al. 1999). Also within the Cichlidae, there are some species that are characterised by similar ontogenetic changes in their diets and pharyngeal jaw morphologies and dentitions (e.g., Huysseune et al. 1994, Hulsey et al. 2006, Binning \& Chapman 2008). This is particularly true for the Alluad's haplo, Astatoreochromis alluaudi Pellegrin, 1904, the Midas cichlid Amphilophus citrinellus (Günther, 1864), and the Minkleyi's cichlid Herichtys minkleyi (Kornfield \& Taylor, 1983). In all comparative extant species, this dietary shift is not a sudden event but a gradual transition (Fig. 15).

Similar to the dietary switches that were discussed before, in $R$. minuta, the majority of the small as well as larger specimens with preserved food remains, obviously belonged to the "shell cracker" type of their pharyngeal dentition. Nevertheless, this predominance simply may result from the technical difficulties to detect the delicate type of pharyngeal teeth in small individuals (see section "Investigation and documentation"). As a matter of fact, conspecific fish as prey can be found in those specimens that are characterized by the molariform (e.g., HLMD-Me 12505 ) and the more massive type of pharyngeal dentition

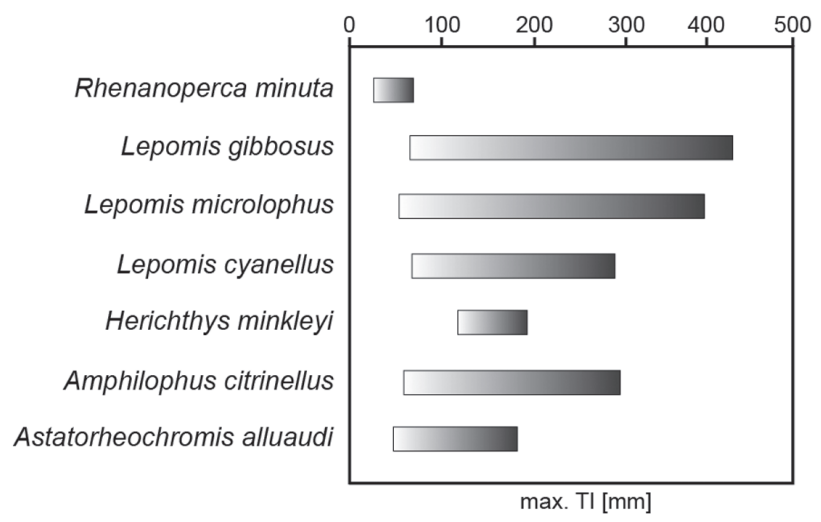

Figure 15. Onset of molluscivory/durophagy of the pharyngeal dentition in Rhenanoperca minuta and comparative extant species. Pumpkinseed, L. gibbosus - data from Sadzikowski \& Wallace (1976), Keast (1978), Osenberg et al. (1994). Gastropods are almost the only prey consumed after $100 \mathrm{~mm} \mathrm{Tl}(80 \mathrm{~mm} \mathrm{S1})$. Redear sunfish, L. microlophus (Günther, 1859) - data from Huish (1957), Keast (1978), Wainwright \& Lauder (1992). Green sunfish, L. cyanellus Rafinesque, 1819 - data from Sadzikowsi \& Wallace (1976). This species has neither the hypertrophied pharyngeal muscles nor the hypertrophied pharyngeal bones that are typical of shell-crackers. Fish can make up $10-65 \%$ of the diet in larger specimens (Mittelbach \& Persson 1998) even though this species will occasionally also feed on gastropods (Wainwright \& Lauder 1992). Minkleyi's cichlid, Herichtys minkleyi (Kornfield \& Taylor, 1983) data from Hulsley et al. (2006), mainly referring to a marked increase in the number of molariform teeth on the lower pharyngeal jaw. Midas cichlid, Amphilophus citrinellus (Günther, 1864) - data from Meyer (1990). Alluad's haplo, Astatoreochromis alluaudi (Pellegrin, 1904) data from Huysseune (1955), Huysseune et al. (1994), mainly referring to the onset of divergence between the two types of pharyngeal jaws.

(e.g., HLMD-Me 15837, HLMD-Me 10352), even when they still are comparatively small $33 \mathrm{~mm} \mathrm{Tl}(27 \mathrm{~mm} \mathrm{Sl})$.

As was already stated in the section "Diet switch in Rhenanoperca minuta", and also according to the cooccurrence of two different basic types of pharyngeal dentition, it can be concluded that the diet switch should have been from a soft-bodied diet to a hard-bodied, probably gastropod-dominated one, rather than from softbodied arthropods to fish as postulated in the literature (Richter \& Baszio 2006). Roundish, robust pharyngeal teeth up to $0.4 \mathrm{~mm}$ in diameter are already present in small individuals of about $28 \mathrm{~mm} \mathrm{Tl}(23 \mathrm{~mm} \mathrm{Sl}$; HLMD-Me 15977). This means that the switch must have must have taken place very early, which is most unusual for all extant Centrarchidae and Cichlidae with the molariform type of pharyngeal dentition (Fig. 15). Moreover, at least in those specimens with identifiable contents of the digestive tract, the development of the strong or even molariform pharyngeal dentition does not seem to depend on growth: it was recorded from rather small-sized as well as larger individuals (32-72 $\mathrm{mm} \mathrm{Tl}, 26-58 \mathrm{~mm} \mathrm{Sl}$, respectively). The same probably applies to the alternative type that at least is present also in rather small individuals of about the same size. It therefore seems likely that both were a priori 
co-existent in the same habitat. Such a considerable intraspecific variation with strong population-level local adaptations is known from extant centrachids (L. gibbosus), where it was ascribed to phenotypic plasticity (Mittelbach et al. 1999). Nevertheless, the co-existence of such different morphotypes has also been ascribed to, or at least been discussed in connection with, speciation events elsewhere in the literature (e.g., Schliewen et al. 1994, Wilson et al. 2000, Schliewen et al. 2001). Considering the transitional stages between the two basic types of pharyngeal dentition that are present in R. minuta, together with the large extent of variation in other skeletal elements that is known from this (and also other) Messel fish species (Micklich 1996, Micklich \& Klappert 2004), it is in principle possible to contemplate two options: ongoing speciation or phenotypic plasticity as a response to the exploitation of different food resources or habitat types. As already mentioned in the section "Cannibalism", only certain kinds of soft-bodied prey organisms may have been available all through those profile sections that are dominated by R. minuta (Richter et al. 2017) and hard-shelled prey, like gastropods, was definitely rare. As a consequence, it also should be considered that this type of resource may not have existed in Lake Messel but only in nearby permanent or ephemeral water bodies that at least occasionally were in contact with the lake. Such a scenario is in good correspondence, e.g., with the absence of larger-sized specimens of R. minuta (see section "Diet switch in R. minuta"), as well as with a couple of other peculiarities concerning the Messel fish fauna (Micklich 2012a). It is also consistent with the amphipod remains that were found in at least some specimens and may have been an allochthonous faunal element that was is washed into the lake by temporal affluxes from external water bodies (Richter et al. 2017) rather than an autochthonous one.

\section{Conclusions}

The present study reveals an extraordinarily high rate of evacuated digestive tracts in all Messel fish species studied. This refers to both, the consideration of comparative extant species, as well as a comparison with the published information. These differences are difficult to attribute to methodological shortcomings or artifacts of preservation. Only in Rhenanoperca minuta Gaudant \& Micklich, 1990 they may be ascribed to shortages of suitable prey, and possibly also to other environmental restrictions, which also might serve as a suitable explanation for the occurrence of cannibalism in this species. Furthermore, the differences between the published rates of evacuated digestive tracts in Thaumaturus intermedius Weitzel, 1933 and those of the present study may at least partly be due to different (microstratigraphical) origins of the basic samples. Such explanations, however, cannot be used in the case of the high rates of empty digestive tracts in bowfins and gars, especially as suitable prey items should in principle have been available in sufficient quantities during the periods of time from which the studied specimens were recovered. Therefore, it is more likely that diurnal and/or seasonal changes in their activity and food-intake cycles may have played a major role.

For $R$. minuta, the possibility of a diet switch from predominantly arthropods to fish, especially a switch to T. intermedius as main prey, as it has been reported in literature, can be dismissed. There rather was a gradual transition from feeding on soft-bodied arthropods to predating upon gastropods, at least in the majority of specimens. This switch must have taken place at a very early ontogenetic stage and is not known from comparative extant species of comparable size. In addition, the "merits" of such an early switch, e.g., a rapid gain in the size of those specimens that switched early in life, has not been documented from the Messel fossil record. One possible explanation is habitat segregation. The larger and mature specimens of $R$. minuta might actually have lived in external water bodies that only occasionally were connected to the ancient Lake Messel. This is also consistent with the few finds of amphipod remains in the digestive tracts, which probably were allochthonous elements that were not captured in Lake Messel. The polymorphism of the pharyngeal jaws and dentition, together with other known expressions of morphological variation in this species may be ascribed to phenotypic plasticity, but may just as well be indicative of starting or ongoing speciation. The different morphotypes probably originated in adjacent water bodies (allopatric) rather than in Lake Messel itself (sympatric).

\section{Acknowledgments}

Alexandra Dörsam, Koblenz, Jörg Habersetzer, Frank-furt, Wilhelm Stürmer, Erlangen, and Siegfried Thüngerthal, Frankfurt, helped with numerous detailed radiographs. Michael Wuttke, Griesheim, donated specimens, and †Manfred Keller, Frankfurt am Main, as well Klaus-Dieter Weiß, Fischbach/Ts facilitated the study of materials in their private collections and left specimens to the HLMD under reasonable conditions; Stephan Schaal, Frankfurt am Main, provided access to the extensive Messel collection of the Senckenberg Research Institute; Alexandra Littkeiz, Darmstadt, and Daniel Schröder, Osthofen, helped with the documentation of the contents of the digestive tracts. Thomas M. Ulber (www.herprint.com) improved the English. VB's work is kindly funded by the Volkswagen Foundation (Lichtenberg professorship to Joachim T Haug). Erin Maxwell, Stuttgart, and Ilja Kogan, Freiberg, reviewed the manuscript and helped with useful suggestions for improvements. 


\section{References}

Andreae, A. 1893. Vorläufige Mitteilung über die Ganoiden (Lepisosteus und Amia) des Mainzer Beckens. Verhandlungen des naturhistorisch-medizinischen Vereins, Neue Folge 5, $7-15$.

Barel, C.D.N., van Oijen, M.J.P., Witte, F. \& Witte-Maas, E.L.M. 1977. An introduction to the taxonomy and morphology of the haplochromine Cichlidae from Lake Victoria. Part A + B. Netherlands Journal of Zoology 27(4), 333-389. DOI 10.1163/002829677X00207

Berry, F.H. 1955. Food of the mudfish (Amia calva) in Lake Newnan, Florida, in relation to its management. Quarterly Journal of the Florida Academy of Sciences 18(1), 69-75.

Binning, S.A. \& Chapman, L.J. 2008. Feeding ecology and diet overlap in riverine chichlids from western Uganda. Verhandlungen der Internationalen Vereinigung für Limnologie 30(2), 283-286. DOI 10.1080/03680770.2008.11902127

Boy, J.A. 2003. Paläoökologische Rekonstruktion von Wirbeltieren: Möglichkeiten und Grenzen. Paläontologische Zeitschrift 77(1), 123-152. DOI 10.1007/BF03004564

CARLANDER, K.D. 1977. Handbook of freshwater fishery biology, Vol. II. 431 pp. Iowa State University Press, Ames.

CARlander, K.D. 1997. Handbook of freshwater fishery biology, Vol. III. 418 pp. Iowa State University Press, Ames.

Craig, J.F. 2000. Percid fishes. Systematics, ecology and exploitation. 370 pp. Blackwell Sciences Ltd., Malden. DOI 10.1002/9780470696033

Cuvier, G. \& Valenciennes, A. 1829. Histoire naturelle des poissons, Vol. 3. Des percoïdes à dorsale unique à sept rayons branchiaux et à dents en velours ou en cardes. 500 pp. Levrault, Paris.

DeKaY, J.E. 1842. Zoology of New-York, or the New-York fauna; comprising detailed descriptions of all the animals hitherto observed within the state of New-York, with brief notices of those occasionally found near its borders, and accompanied by appropriate illustrations. Part IV. $415 \mathrm{pp}$. White \& Visscher, Albany. DOI 10.5962/bhl.title.13735

DianA, M.C. 1966. Diet of the bowfin in Central Florida. Quarterly Journal of the Florida Academy of Sciences 29(4), 276-284.

Donald, D.B. \& Kooyman, A.H. 1977. Food, feeding habits, and growth of goldeye, Hiodon alosoides (Rafinesque), in waters of the Peace-Athabasca Delta. Canadian Journal of Zoology 55, 1038-1047. DOI 10.1139/z77-132

Dugas, C.N., Konikoff, M. \& Trahan, M.F. 1976. Stomach contents of bowfin (Amia calva) and spotted gar (Lepisosteus oculatus) taken in Henderson Lake, Louisiana. Proceedings of the Louisiana Academy of Sciences 39, 28-34.

EiKAmp, H. 1982. Allzuviel ist ungesund. Beutefisch in der Bauchhöhle eines Schlammfisches. Mineralien-Magazin 3, 112-113.

Gaudant, J. \& Micklich, N. 1990. Rhenanoperca minuta nov. gen., nov. sp., ein neuer Percoide (Pisces, Perciformes) aus der Messel-Formation (Mittel-Eozän, Unteres Geiseltalium). Paläontologische Zeitschrift 64, 269-286.

DOI 10.1007/BF02985719
George, E.L. \& Hadley, W.F. 1979. Food and habitat partitioning between rock bass (Ambloplites rupestris) and smallmouth bass (Micropterus dolomieui) young of the year. Transactions of the American Fisheries Society 108, 253-261.

DOI 10.1577/1548-8659(1979)108<253:FAHPBR>2.0.CO;2

Gerkin, S.D. 1994. Feeding ecology of fish. 418 pp. Academic Press, San Diego.

Goldspink, C.R. \& Goodwin, D. 1979. A note on the age composition, growth rate and food of perch Perca fluviatilis (L.) in four eutrophic lakes, England. Journal of Fish Biology 14, 489-505. DOI 10.1111/j.1095-8649.1979.tb03547.x

GottFried, M.D. 1986 Developmental transition in feeding morphology of the Midas Cichlid. Copeia 1986(4), 1028-1030. DOI 10.2307/1445308

Grande, L. 2010. An empirical synthetic pattern study of Gars (Lepisosteiformes) and closely related species, based mostly on skeletal anatomy. American Society of Ichthyologists and Herpetologists Special Publication 6, 1-871.

Grande, L. 2013. The lost world of Fossil Lake: Snapshots from Deep Time. 432 pp. University of Chicago Press, Chicago. DOI 10.7208/chicago/9780226922980.001.0001

Grande, L. \& Bemis, W.E. 1998. A comprehensive phylogenetic study of amiid fishes (Amiidae) based on comparative skeletal anatomy. An empirical search for interconnected patterns of natural history. Society of Vertebrate Paleontology, Memoir 4, Journal of Vertebrate Paleontology 18(1), 1-690.

DOI 10.1080/02724634.1998.10011114

Greenwood, P.G. 1972. Morphology, endemism and speciation in African cichlid fishes. Verhandlungen der Deutschen Zoologischen Gesellschaft 1972, 115-124.

Grein, M., Utescher, T., Wilde, V. \& Roth-Nebelsick, A. 2011. Reconstruction of the middle Eocene climate of Messel using palaeobotanical data. Neues Jahrbuch für Geologie und Paläontologie, Abhandlungen 260(3), 305-318.

DOI 10.1127/0077-7749/2011/0139

GÜNTHER, A. 1859. Catalogue of the acanthopterygian fishes in the collection of the British Museum. Gasterosteidae, Berycidae, Percidae, Aphredoderidae, Pristipomatidae, Mullidae, Sparidae. 524 pp. British Museum (Natural History), London. Günther, A. 1864. Report of a collection of fishes made by Messrs, Dow, Godman, and Salvin in Guatemala. Proceedings of the Zoological Society of London 1864, 144-154.

Herting, G.E. \& Witt, A. 1968. Rate of digestion in the Bowfin. Progressive Fish-Culturist 30(1), 26-28. DOI 10.1577/1548-8640(1968)30[26:RODITB]2.0.CO;2

Huish, M.T. 1957. Food habits of three Centrarchidae in Lake George, Florida. Proceedings of the Southeastern Association of Game and Fish Commissioners 11, 293-303.

Hulsley, C.D., Marks, J., Hendrickson, D.A., Williamson, C.A., Cohen, A.E. \& Tephens, M.J. 2006. Feeding specialisation in Herichthys minckleyi, a trophically polymorphic fish. Journal of Fish Biology 68, 1399-1410. DOI 10.1111/j.0022-1112.2006.01021.x

Hunt, B.P. 1960. Digestion rate and food consumption of Florida Gar, Warmouth, and Largemouth Bass. Transactions of the American Fisheries Society 89(2), 206-211.

DOI 10.1577/1548-8659(1960)89[206:DRAFCO]2.0.CO;2 
Huysseune, A. 1995. Phenotypic plasticity in the lower pharyngeal jaw dentition of Astatoreochromis alluaudi (Teleostei: Cichlidae). Archives of Oral Biology 40(11), 1005-1014. DOI 10.1016/0003-9969(95)00074-Y

Huysseune, H., Sire, J.Y. \& Meunier, F.P. 1994. Comparative study of the lower pharyngeal jaw structure in two phenotypes of Astatoreochromis alluaudi (Teleostei: Cichlidae). Journal of Morphology 221, 25-43.

DOI 10.1002/jmor.1052210103

JuANES, F. 2003. The allometry of cannibalism in piscivorous fish. Canadian Journal of Fisheries and Aquatic Sciences 60, 594-602. DOI 10.1139/f03-051

Juanes, F., Buckel, J.A. \& Scharf, F.S. 2002. Feeding ecology of piscivorous fishes, 267-283. In HART, P.J.B. \& REYNOLDS, J.D. (eds) Handbook of Fish Biology and Fisheries, Vol 1. Wiley-Blackwell, Malden.

KAISER, T. \& MickLICH, N. 1995. Schnellpräparation von MesselFossilien zum Erstellen einer osteologischen Referenzsammlung. Präparator 41(2), 69-72.

Keast, A. 1968. Feeding biology of the Black crappie, Pomoxis nigromaculatus. Journal of the Fisheries Research Board of Canada 25(2), 285-297. DOI 10.1139/f68-024

KEAST, A. 1978. Feeding interrelations between age groups of Pumpkinseed (Lepomis gibbosus) and comparisons with Bluegill (Lepomis macrochirus). Journal of the Fisheries Research Board of Canada 35, 12-27. DOI 10.1139/f78-003

Keast, A. \& Welsh, L. 1968. Daily feeding periodicities, food uptake rates, and dietary changes with the hour of day in some lake fishes. Journal of the Fisheries Research Board of Canada 25(6), 1133-1144. DOI 10.1139/f68-099

KiRTLAND, J.P. 1840. Descriptions of four new species of fishes. Boston Journal of Natural History 3(1-2), 273-277.

Kofron, C.P. \& Schreiber, A.A. 1983. The central mudminnow (Umbra limi) in Missouri, with an analysis of summer foods. Southwestern Naturalist 28(3), 371-372. DOI $10.2307 / 3670800$

KoRnFIELd, I. \& TAYLOR, J.N. 1983. A new species of polymorphic fish, Cichlasoma minckleyi, from Cuatro Ciénegas, Mexico (Teleostei: Cichlidae). Proceedings of the Biological Society of Washington 96(2), 253-269.

LACÉPÈDE, B.G.E. 1802. Histoire naturelle des poissons. Vol. 4. 728 pp. Plassan, Paris.

Lagler, K.F. \& Applegate, V.C. 1942. Further studies of the food of the bowfin (Amia calva) in Southern Michigan, with notes on the inadvisability of using trapped fish in food analyses. Copeia 1942(3), 190-191. DOI 10.2307/1438230

Lagler, K.F. \& Hubbs, F.V. 1940. Food of the Long-nosed Gar (Lepisosteus osseus oxyurus) and the Bowfin (Amia calva) in Southern Michigan. Copeia 1940(4), 239-241. DOI $10.2307 / 1438577$

LAGLeR, K.F. \& WatTS, J. 2004. Food of bowfins (Amia calva) from the Muskegon River at Houghton Lake, Roscommon County, Michigan. Michigan University Fisheries Research Report 569, 2 pp.

Lambou, V.W. 1962. The alligator gar. Wildlife Education Bulletin 30, 2-8.

LANGTON, R.W. 1977. A review of methods used for estimating gut evacuation rates and calculating daily ration for fish. Woods Hole Laboratory Reference 77-07, 1-26.

LASKAR, K.S. 1942. Wachstum und Ernährung des Barsches (Perca fluviatilis L.) in ostholsteinischen Seen. Archiv für Hydrobiologie 49, 1009-1026.

Lesueur, C.A. 1829. Cantharus nigromaculatus, 88. In Cuvier, G. \& VAlenciennes, A. (eds) Histoire naturelle des poissons, Vol. 3. Des percoïdes à dorsale unique à sept rayons branchiaux et à dents en velours ou en cardes. Levrault, Paris.

LiEM, K.F. 1979. Evolutions-Schub in Ostafrika. Wie Buntbarsche zu Räubern wurden. Spektrum der Wissenschaft 1979(5), 90-102.

Linnaeus, C. 1758. Systema naturae per regna tria naturae, secundum classes, ordines, genera, species, cum characteribus, differentiis, synonymis, locis. $10^{\text {th }}$ ed., Vol. 1.824 pp. Laurentii Salvii, Holmiae. DOI 10.5962/bhl.title.542

LinNAEus, C. 1766. Systema naturae sive regna tria naturae, secundum classes, ordines, genera, species, cum characteribus, differentiis, synonymis, locis. $12^{\text {th }}$ ed., Vol. $1.532 \mathrm{pp}$. Laurentii Salvii, Holmiae.

DOI 10.5962/bhl.title.68927

Lombardi, S.E. 2009. Predation by Eastern Mudminnows (Umbra pygmaea) on macroinvertebrates of temporary wetlands. 45 pp. Master thesis, Maryland University, Maryland, USA.

McGrath, E.P., Hilton, E.J. \& Musick, J.A. 2013. Temporal and spatial effects on the diet of an estuarine piscivore, longnose gar (Lepisosteus osseus). Estuaries and Coasts 36(6), 1292-1303. DOI 10.1007/s12237-013-9637-9

Meyer, A. 1990. Morphometrics and allometry in the trophically polymorphic cichlid fish, Cichlasoma citrinellum: Alternative adaptations and ontogenetic changes in shape. Journal of Zoology 221, 237-260.

DOI 10.1111/j.1469-7998.1990.tb03994.x

Micklich, N. 1978. Palaeoperca proxima, ein neuer Knochenfisch aus dem Mittel-Eozän von Messel bei Darmstadt. Senckenbergiana lethaea 59(4/6), 483-501.

Micklich, N. 1985. Biologisch-paläontologische Untersuchungen zur Fischfauna der Messeler Ölschiefer (MittelEozän, Lutetium). Andrias 4, 3-171.

Micklich, N. 1992. Ancient knights-in-armour and modern cannibals, 71-92. In ScHAAL, S. \& ZIEGLER, W. (eds) MesselAn Insight into the History of Life and of the Earth. Clarendon Press, Oxford.

Micklich, N. 1996. Percoids (Pisces, Perciformes) from the oil shale of the Messel Formation (Middle Eocene, Lower Geiseltalian): An ancient diversification? 113-127. In LoBONCervia, J., Elvira, J.B. \& Granado-Lorencio, C. (eds) Fishes and their Environment. Proceedings of the $8^{\text {th }}$ Congress of the Societas Europaea Ichthyologorum (SEI). Instituto Español de Oceanografía, Madrid.

Micklich, N. 2002. The fish fauna of Messel Pit: A nursery school? Courier Forschungsinstitut Senckenberg 237, 97-127.

Micklich, N. 2007. Coincidences or necessities? 585-629. In Gruber, G. \& Micklich, N. (eds) Messel - Treasures of the Eocene. Hessisches Landesmuseum, Darmstadt.

Micklich, N. 2012a. Peculiarities of the Messel fish fauna and 
their palaeoecological implications: a case study. Palaeobiodiversity and Palaeoenvironments 92(4), 585-629.

DOI 10.1007/s12549-012-0106-4

Micklich, N. 2012b. An exceptional record of Thaumaturus intermedius WeItzel, 1933 from Messel Pit. Kaupia 18, 11-17.

Micklich, N. \& DrobeK, M. 2007. 15-21. Mining, excavations, and preparation. In Gruber, G. \& Micklich, N. (eds) MesselTreasures of the Eocene. Hessisches Landesmuseum, Darmstadt.

Micklich, N. \& Klappert, G. 2004. Character variation in some Messel fishes, 137-163. In Arratia, G. \& Tintori, A. (eds) Mesozoic Fishes 3 - Systematics, Palaeoenvironment and Biodiversity. Friedrich Pfeil, Munich.

Micklich, N. \& Mentges, S. 2012. Fin ray fractures in Messel fishes. Kaupia 18, 73-81.

Mittelbach, G.G., Osenberg, C.W. \& Wainwright, P.C. 1999. Variation in feeding morphology between pumpkinseed populations: Phenotypic plasticity or evolution? Evolutionary Ecological Research 1, 111-128.

Mittelbach, G.G. \& Persson, L. 1998. The ontogeny of piscivory and its ecological consequences. Canadian Journal of Fisheries and Aquatic Sciences 55, 1454-1465.

DOI 10.1139/f98-041

MolnáR, G., TAmassy, E. \& Tölg, I. 1967. The gastric digestion of living, predatory fish, 135-149. In Gerkin, S.D. (ed.) The biological basis of freshwater fish production. Blackwell, Oxford \& Edinburgh.

Moon, D.N., Fisher, S.J. \& Krentz, S.C. 1998. Assessment of larval fish consumption by Goldeye (Hiodon alosoides) in two Missouri river backwaters. Journal of Freshwater Ecology 13(3), 317-321. DOI 10.1080/02705060.1998.9663624

Nawrocki, B., Colborne, S.F., Yurkowski, D.J. \& Fisk, A.T. 2016. Foraging ecology of Bowfin (Amia calva), in the Lake Huron-Erie Corridor of the Laurentian Great Lakes: Individual specialists in generalist populations. Journal of Great Lakes Research 42, 1452-160.

DOI 10.1016/j.jglr.2016.08.002

Netsch, N.F. \& Witt, A. JR. 1962. Contributions to the life history of the Longnose gar, (Lepisosteus osseus) in Missouri. Transactions of the American Fisheries Society 91(3), 251-262.

DOI 10.1577/1548-8659(1962)91[251:CTTLHO]2.0.CO;2

Neubert, E. 1999. The mollusca of the Eocene lake of Messel. Courier Forschungsinstitut Senckenberg 216, 167-181.

Nikolova, M., Uzunova, E., Studenkov, S., Georgieva, M., Pehlinvanov, L. \& Velkov, B. 2008. Feeding patterns and seasonal variation in the diet of nonindigenous fish species Lepomis gibbosus L. from shallow eutrophic lakes along River Vit, Bulgaria. Natura Montenegrina 7(3), 71-85.

North American Native Fish Association. 2015. Fish in focus: Bowfin young-of-the-year, Amia calva. www.nanfa.org/fifl bowfin.shtml

O'Goghain, A., Falcon-Lang, H.J., Carpenter, D., Miller, R.F., Benton, M.J., Davies, T., Pufahl, P.K., Ruta, M., Hinds, S. \& Stimson, M. 2016. Fish and tetrapod communities across a marine to brackish salinity gradient in the Pennsylvanian (early Moscovian) Minto Formation of New Brunswick,
Canada, and their palaeoecological and palaeogeographic implications. Palaeontology 59, 689-724.

DOI 10.1111/pala.12249

Osenberg, C.W., Olson, M.H. \& Mittelbach, G.G. 1994. Stage structure in fishes: Resource productivity and competition gradients, 151-170. In Stouder, D.J., Fresh, K.L., Feller, R.J. \& BARUCH, B.W. (eds) Therory and Application in fish Feeding Ecology. University of South Carolina Press, Columbia.

PaneK, F.M. \& Weis, J.S. 2013. Diet of eastern mudminnow (Umbra pygmaea DeKay) from two geographically distinct populations within the North American native range. Northeastern Naturalist 20(1), 37-48.

DOI 10.1016/j.jglr.2016.08.002

Peckham, R.S. \& Dineen, C.F. 1957. Ecology of the central mudminnow, Umbra limi (Kirtland). American Naturalist 58(1), 222-231. DOI 10.2307/2422370

Pellegrin, J. 1904. Contribution à l'étude anatomique, biologique et taxinomique des poissons de la famille des Cichlidés. Mémoires de la Société Zoologique de France 16, 41-400.

Rafinesque, C.S. 1819. Prodrome de 70 nouveaux genres d'animaux découverts dans l'intérieur des États-Unis d'Amérique, durant l'année 1818. Journal de Physique, de Chimie et d'Histoire Naturelle 88, 417-429.

RAFINESQUE, C.S. 1820. Fishes of the Ohio River. Western Revue and Miscellaneous Magazine 1(6), 361-377.

Richter, G. 1992. Fossilized gut contents: analysis and interpretation, 71-92. In SchaAl, S. \& Ziegler, W. (eds) Messel An Insight into the History of Life and of the Earth. Clarendon Press, Oxford.

Richter, G. \& BAszio, S. 2001a. Traces of a limnic food web in the Eocene Lake Messel - a preliminary report based on fish coprolite analyses. Palaeogeography, Palaeoclimatology, Palaeoecology 166, 345-368.

DOI 10.1016/S0031-0182(00)00218-2

Richter, G. \& BAszio, S. 2001b. First proof of planctivory/ insectivory in a fossil fish: Thaumaturus intermedius from the Eocene Lake Messel (FRG). Palaeogeography, Palaeoclimatology, Palaeoecology 173, 75-85.

DOI 10.1016/S0031-0182(01)00318-2

Richter, G. \& BAszio, S. 2006. First evidence of size-related change of diet ("switching") in a fossil fish. Palaeogeography, Palaeoclimatology, Palaeoecology 237, 270-279.

DOI 10.1016/j.palaeo.2005.12.005

Richter, G. \& Wedmann, S. 2005. Ecology of the Eocene Lake Messel revealed by analysis of small fish coprolites and sediments from a drilling core. Palaeogeography, Palaeoclimatology, Palaeoecology 223, 147-161. DOI 10.1016/j.palaeo.2005.04.002

Richter, G., Baszio, S. \& Wuttke, M. 2017. Discontinuities in the microfossil record of middle Eocene Lake Messel: clues for ecological changes in lake's history? Palaeobiodiversity and Palaeoenvironments 97(2), 295-314. DOI 10.1016/j.palaeo.2005.04.002

Roth, R. \& Micklich, N. 2006. Eine neue Methode zur Präparation kleiner Messel-Fossilien. Präparator 52, 64-67.

Sadzikowski, M.R. \& Wallace, D.C. 1976. A comparison of the food habits of size classes of three sunfishes (Lepomis 
macrochirus Rafinesque, L. gibbosus (Linnaeus) and L. cyanellus Rafinesque). American Midland Naturalist 95(1), 220-225. DOI 10.2307/2424252

Schatal, S. \& Rabenstein, R. 2012. Fossilienfundstätte Grube Messel - Übersichtskarten zur Betriebs- und Grabungsplanung. Forschungsinstitut Senckenberg, Arbeitsbereich Messelforschung. http://www.senckenberg.de/files/ content/forschung/abteilung/messelforschung/schaal rabenstein_2012_nfm_me-karte.pdf

SchaAl, S. \& Ziegler, W. (eds) 1992. Messel - An insight into the history of life and of the earth. 322 pp. Clarendon Press, Oxford; Oxford University Press, New York.

Schliewen, U.K., Tautz, D. \& PäÄBo, S. 1994. Sympatric speciation suggested by monophyly of crater lake cichlids. Nature 368(6472), 629-632. DOI 10.1038/368629A0

Schliewen, U.K., Rassmann, K., Markmann, M., Markert, J., Kocher, T. \& TAutz, D. 2001. Genetic and ecological divergence of a monophyletic cichlid species pair under fully sympatric conditions in Lake Ejagham, Cameroon. Molecular Ecology 10(6), 1471-1488.

DOI 10.1046/j.1365-294X.2001.01276.x

SмIтH, L.S. 1980. Digestion in teleost fishes. In FAO (ed.) Fish feed technology. Lectures presented at the FAO/UNDP Training Course in Fish Feed Technology, Seattle, Washington (USA), 9October-15 December 1978. UNDP/FAO, ADCP/REP/80/11. Rome. http://www.fao.org/3/x5738e/x5738e00 htm\#Contents

Smith, C. \& Reay, P. 1991. Cannibalism in teleost fish. Reviews in Fish Biology and Fisheries 1, 41-64. DOI 10.1007/BF00042661

Smylie, M., Shervette, V. \& McDonough, C. 2015. Prey composition and ontogenetic shift in coastal populations of longnose gar Lepisosteus osseus. Journal of Fish Biology 87(4), 815-1128. DOI 10.1111/jfb.12759

Storch, G. 2001. Palaeobiological implications of the Messel mammalian assemblage, 215-235. In GunNell, G.F. (ed.) Eocene biodiversity: Unusual occurrences and rarely sampled habitats. Springer, Boston.

Tseitlin, V.B. 1980. Duration of gastric digestion in fishes. Marine Ecology Progress Series 2, 277-280.

DOI 10.3354/meps002277
Tyler, J.D. \& Granger, M.N. 1984. Notes on food habits, size, and spawning behaviour of Spotted gar in Lake Lawtonka, Oklahoma. Proceedings of the Oklahoma Academy of Sciences 64, 8-10.

Wainwright, P.C. \& Lauder, G.V. 1992. The evolution of the feeding biology in sunfishes (Centrarchidae), 472-491. In Mayden, R.L. (ed.) Systematics, Historical Ecology \& North American Freshwater Fishes. Stanford University Press, Stanford. DOI 10.2307/2389554

Wainwright, P.C., Osenberg, C.W. \& Mittelbach, G.G. 1991. Trophic polymorphism in the Pumpkinseed Sunfish (Lepomis gibbosus Linnaeus): Effects of environment on ontogeny. Functional Ecology 5(1), 40-55. DOI 10.2307/2389554

Walbaum, J.J. 1792. Petri Artedi sueci genera piscium. In quibus systema totum ichthyologiae proponitur cum classibus, ordinibus, generum characteribus, specierum differentiis, observationibus plurimis. Redactis speciebus 242 ad genera 52.723 pp. Rose, Greifswald.

Wedmann, S. \& Richter, G. 2007. The ecological role of immature phantom midges (Diptera, Chaoboridae) in the Eocene Lake Messel, Germany. African Invertebrates 48(1), 59-70.

Weitzel, K. 1933. Amphiperca multiformis n.g. n.sp. und Thaumaturus intermedius n.sp., Knochenfische aus dem Mitteleozän von Messel. Notizblatt des Vereins für Erdkunde und der Hessischen Geologischen Landesanstalt V(14), 89-97.

WERnER, E.E. 1974. The fish size, prey size, handling time relation in several sunfishes and some implications. Journal of the Fisheries Research Board of Canada 31(9), 1531-1536. DOI 10.1139/f74-186

Wichard, W., Gröhn, C. \& Seredszus, F. 2009. Aquatic insects in Baltic amber. 335 pp. Kessel Publishers, Remagen.

Wilson, A.K., Noack-Kunnemann, K. \& Meyer, A. 2000. Incipient speciation in sympatric Nicaraguan crater lake cichlid fishes: sexual selection, versus ecological diversification. Proceedings of the Royal Society of London, B 267, 2133-2141. DOI 10.1098/rspb.2000.1260

Zapata, S.C. \& Granado-Lorencino, C. 1993. Age, growth and feeding of the exotic species Lepomis gibbosus in a Spanish cooling reservoir. Archiv für Hydrobiologie, Supplement 90, 561-573. 